\title{
Simple Hybrids Based on Mo or W Oxides and Diamines: Structure Determination and Catalytic Properties
}

\author{
Barbara Bożek $^{1}$ (D) Patrícia Neves ${ }^{2}$ (D) Marcin Oszajca $^{3}$ (D) - Anabela A. Valente ${ }^{2}$ (D) Jan Połtowicz ${ }^{1}$ (D) \\ Katarzyna Pamin ${ }^{1}$ (D) . Wiesław Łasocha ${ }^{1,3}$ (D)
}

Received: 23 May 2019 / Accepted: 2 September 2019 / Published online: 14 September 2019

(c) The Author(s) 2019

\section{Abstract}

Crystalline hybrid catalysts based on molybdenum or tungsten oxide and aliphatic diamines were synthesized via simple, ecofriendly reproducible methodologies, starting from commercially available and relatively inexpensive organic and inorganic precursors, and using water as solvent under mild conditions. The crystal structures of the obtained fine powdered solids were solved ab initio from powder X-ray diffraction data. The type of organic component (1,2-diaminoethane, 1,2-diaminopropane, 1,3-diaminopropane) may play a structure-directing role. On the other hand, different metals $(\mathrm{M}=\mathrm{Mo}, \mathrm{W}) \mathrm{may}$ lead to isostructural one-dimensional hybrids of the type $\mathrm{MO}_{3}(\mathrm{~L})$ with the same bidentate diamine ligand L. The prepared catalysts were investigated for the liquid phase oxidation of saturated and unsaturated hydrocarbons (cis-cyclooctene, cyclooctane), using different types of oxidants $\left(\mathrm{O}_{2}, \mathrm{H}_{2} \mathrm{O}_{2}\right.$, tert-butyl hydroperoxide). Differences in catalytic performances associated with distinct structural features were investigated.

\section{Graphic Abstract}

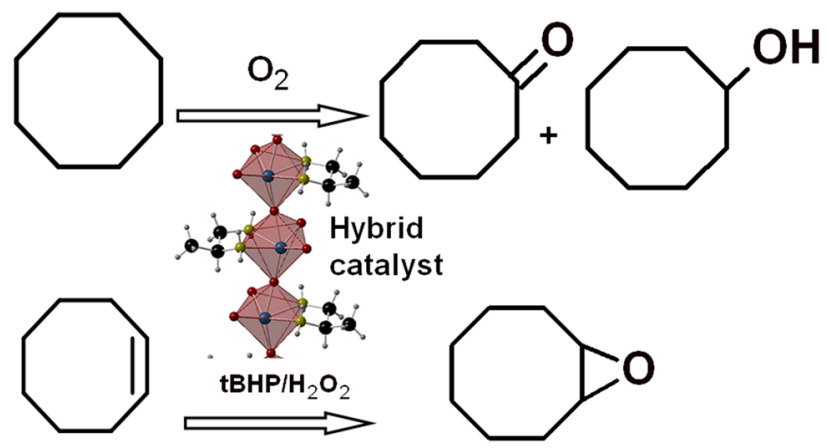

Keywords Hydrocarbons oxidation and epoxidation $\cdot$ Hybrid materials $\cdot$ Crystal structure determination $\cdot$ X-ray powder diffraction

\section{Electronic supplementary material The online version of this article (https://doi.org/10.1007/s10562-019-02935-z) contains supplementary material, which is available to authorized users.}

Anabela A. Valente

atav@ua.pt

Wiesław Łasocha

nclasoch@cyf-kr.edu.pl
2 CICECO - Aveiro Institute of Materials, University of Aveiro, 3810-193 Aveiro, Portugal

3 Faculty of Chemistry, Jagiellonian University, Gronostajowa 2, 30-387 Krakow, Poland

Jerzy Haber Institute of Catalysis and Surface Chemistry,

Polish Academy of Sciences, Niezapominajek 8,

30-239 Krakow, Poland 


\section{Introduction}

Inorganic-organic polymeric hybrids based on molybdenum and tungsten oxide and diamines, with the general formula $\left\{\mathrm{MO}_{3}\left(\mathrm{NH}_{2}\right)_{2} \mathrm{R}\right\}$ where $\mathrm{M}=\mathrm{Mo}, \mathrm{W}$, have been described in the recent literature [1-6]. These compounds have attracted considerable attention because of their interesting structural architectures and properties [7, 8]. Specifically, these types of hybrids possess catalytic activity for saturated hydrocarbons oxidation and olefins epoxidation, which are important chemical reactions [1-3, 5, 6]. For example, olefin epoxidation is a key to produce major commodity chemicals such as, ethylene oxide and propylene oxide, used as intermediates for producing a variety of chemicals (including diols) for different end-use industries such as, packaging, electronics, automotive, construction, textile, furnishing and pharmaceutical [9]. Dow Chemical Company is the largest producer of propylene oxide in the world (year 2017) [10]; on the other hand, ca. $15 \%$ of the current global propylene oxide capacity uses processes based on epoxidation with tert-butyl hydroperoxide ( $t \mathrm{bhp}$ ) as oxidant, developed by different companies [10]. Several epoxide chemicals are produced in smaller scale for special applications, such as pharmaceuticals, polymers for biomedicine and cosmetics $[9,11]$.

Hybrids of the type $\left\{\mathrm{MO}_{3}\left(\mathrm{NH}_{2}\right)_{2} \mathrm{R}\right\}$ described in the literature are essentially based on bipyridine and other aromatic amines as organic components [4, 7, 8, 12]. Hybrid analogues based on (simple, commercially available) aliphatic linear diamines have not yet been described in the literature, except $\mathrm{WO}_{3}$ (1,2-diaminoethane) [13] (CSD refcode PIGXOT), to the best of our knowledge. One of the reasons for the lack of scientific advancement on the simplest group of hybrids of the type $\left\{\mathrm{MO}_{3}\left(\mathrm{NH}_{2}\right)_{2} \mathrm{R}\right\}$ may be, at least partly, due to the fact that they are obtained as very fine powders (ascertained experimentally in the present work), which prevents structure determination by single crystal X-ray diffraction technique.

In this work, we aimed at the preparation and challenging structural determination of simple hybrids of the type $\left\{\mathrm{MO}_{3}\left(\mathrm{NH}_{2}\right)_{2} \mathrm{R}\right\}$ where $\mathrm{M}=\mathrm{Mo}, \mathrm{W}$, which are based on molybdenum or tungsten oxide and aliphatic diamines, and investigated their performances for liquid phase oxidation of unsaturated and saturated hydrocarbons, in batch mode. The compounds were prepared via easy and clean methodologies, involving eco-friendly aqueous phase reactions of commercially available and relatively cheap metal and organic precursors, specifically, $\mathrm{MO}_{3}$ and short-chain diamines, under relatively mild conditions. The organic precursors used were 1,2-diaminopropane (1,2-dap), 1,2-diaminoethane (1,2-dae) and 1,3-diaminopropane (1,3-dap). For 1,2-dap and 1,2-dae the spacer group between the chelating amine groups was shortened down to the $-\mathrm{CH}_{2} \mathrm{CH}_{2}-$ fragment (Scheme 1). Structure determination by ab initio $\mathrm{X}$-ray powder diffraction techniques confirmed the formation of the simplest hybrids belonging to the $\left\{\mathrm{MO}_{3}\left(\mathrm{NH}_{2}\right)_{2} \mathrm{R}\right\}$ family, with $\mathrm{R}$ being the $-\mathrm{CH}_{2} \mathrm{CH}_{2}-$ group. While isostructural analogues may be obtained by changing the type of metal, the use of different aliphatic diamines may play a structure-directing role.

\section{Experimental}

\subsection{Materials}

Molybdenum(VI) oxide ( $\geq 99.5 \%)$, tungsten oxide $(\geq 99 \%)$, 1,2-diaminopropane (1,2-dap, 99\%), 1,2-diaminoethane (1,2-dae, $\geq 99.5 \%)$, 1,3-diaminopropane (1,3-dap, $\geq 99 \%$ ), were obtained from Sigma-Aldrich and used as received in the syntheses of the compounds.

For the catalytic tests, cis-cyclooctene (Cy, 95\%, Aldrich), undecane ( $\geq 99 \%$, Aldrich), tert-butylhydroperoxide ( $t$ bhp, 5.5 M in decane, Sigma-Aldrich), $\mathrm{H}_{2} \mathrm{O}_{2}$ (30\% aq., Sigma-Aldrich), acetonitrile (99.9\%, Panreac), anhydrous trifluoromethylbenzene (tfmb, ( $\geq 99 \%$, Aldrich), 1,2-dichloroethane (dce, 99\%, Aldrich), butyl-3-methylimidazolium tetrafluoroborate ([bmim $] \mathrm{BF}_{4}, 98 \%$, iolitec), butyl-3-methylimidazolium bis(trifluoromethanesulfonyl)imide ([bmim] $\mathrm{NTf}_{2}, 98 \%$, iolitec) and butyl-3-methylimidazolium hexafluorophosphate ([bmim] $\mathrm{PF}_{6}, 98 \%$, iolitec), diethyl ether (p.a., Sigma-Aldrich), pentane (95\%, Carlo Erba) and acetone (99.5\%, Aldrich) were acquired from commercial sources and used as received.

\subsection{Synthesis of the Compounds}

An easy, clean synthesis methodology was used for preparing the molybdenum and tungsten compounds, under similar conditions. Specifically, a mixture of $\mathrm{MoO}_{3}(0.01 \mathrm{~mol})$, $\mathrm{H}_{2} \mathrm{O}(30 \mathrm{~mL})$ and the selected diamine $(15 \mathrm{~mL})$ was refluxed until complete dissolution. The excess of liquid fraction was removed by evaporation $\left(75^{\circ} \mathrm{C}\right)$. The precipitate was dried under vacuum (30 mbar) at $100{ }^{\circ} \mathrm{C}$ for $12 \mathrm{~h}$. The final solids

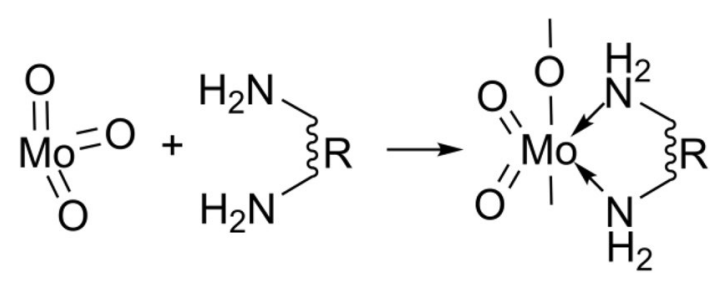

Scheme 1 Hybrids formed from the reaction of $\mathrm{MoO}_{3}$ with diamines ( $\mathrm{R}$ - denotes aliphatic or aromatic groups) 
were stored in desiccators. The obtained hybrids are denoted $\mathrm{MoO}_{3}$ (1,2-dap) 1, $\mathrm{MoO}_{3}\left(1,2\right.$-dae) 2 and $\mathrm{MoO}_{4}(1,3$-dapH 2$) 3$. The tungsten-amine hybrid $\mathrm{WO}_{3}$ (1,2-dap) 4 was prepared in a similar fashion to $\mathbf{1}$, using $\mathrm{WO}_{3}$ instead of $\mathrm{MoO}_{3}$.

The syntheses of tungsten compounds using 1,2-dae or 1,3-dap instead of 1,2-dap resulted in compounds possessing amorphous features (ascertained by X-ray diffraction), and thus were not considered for this work. The yields of the materials prepared were in the range $65-80 \%$.

\subsection{1 $\mathrm{MoO}_{3}(1,2-$ dap $) 1$.}

Anal. Calcd for $\mathrm{MoO}_{3}\left(\mathrm{C}_{3} \mathrm{H}_{10} \mathrm{~N}_{2}\right)(218.046 \mathrm{~g} / \mathrm{mol})$ : C, $16.52 ; \mathrm{N}, 12.85 ; \mathrm{H}, 4.62 \%$. Found: C, $16.85 \%$; N $12.89 \%$; $\mathrm{H}, 4.538 \%$. Selected FT-IR ATR bands $\left(\mathrm{cm}^{-1}\right)$ with assignments based on comparisons to literature data for different compounds ( $s h$ shoulder, $b$ broad, $v w$ very weak, $w$ weak, $m$ medium, $v s$ very strong): $[3,12,14,15] \nu=3215 \mathrm{bm}$ $\left(\mathrm{v}\left(\mathrm{NH}_{2}\right)\right), 3124 \mathrm{~m}\left(\mathrm{v}\left(\mathrm{NH}_{2}\right)\right), 2939 \mathrm{vw}\left(\mathrm{v}\left(\mathrm{CH}_{2}\right)\right), 2879 \mathrm{vw}$ $\left(\mathrm{v}\left(\mathrm{CH}_{2}\right)\right), 1610 \mathrm{w}\left(\delta\left(\mathrm{NH}_{2}\right)\right.$ scissor $), 1566 \mathrm{vw}\left(\delta\left(\mathrm{NH}_{2}\right)\right.$ scissor), $1458 \mathrm{w}\left(\delta\left(\mathrm{CH}_{2}\right)\right.$ scissor $), 1380 \mathrm{w}, 1378 \mathrm{w}, 1307 \mathrm{vw}$, $1216 \mathrm{w}, 1166 \mathrm{vw}, 1056 \mathrm{~m}, 1008 \mathrm{~m}, 911 \mathrm{~m}\left(\mathrm{v}_{\mathrm{sym}}(\mathrm{Mo}=\mathrm{O})\right)$, $875 \mathrm{shvw}\left(\mathrm{v}_{\mathrm{asym}}(\mathrm{Mo}=\mathrm{O})\right), 829 \mathrm{vs}(\mathrm{v}(\mathrm{Mo}-\mathrm{O}-\mathrm{Mo})), 686 \mathrm{shvw}$, $632 \mathrm{bvs}\left(\mathrm{v}_{\mathrm{sym}}(\mathrm{Mo}-\mathrm{O}-\mathrm{Mo})\right), 556 \mathrm{shvw}, 480 \mathrm{w}, 455 \mathrm{w}, 381 \mathrm{w}$, $358 v$ v.

\subsection{2 $\mathrm{MoO}_{3}(1,2-$ dae $) 2$.}

Anal. Calcd for $\mathrm{MoO}_{3}\left(\mathrm{C}_{2} \mathrm{H}_{8} \mathrm{~N}_{2}\right)(204.037 \mathrm{~g} / \mathrm{mol}): \mathrm{C}, 11.77$; N, 13.73; H, 3.95\%. Found: C, 12.83\%; N, $13.80 \% ; 3.91 \%$. Selected FT-IR ATR bands $\left(\mathrm{cm}^{-1}\right)$ with assignments based on comparisons to literature data for different compounds: $[12,14,15] \nu=3205 \mathrm{bm}\left(\mathrm{v}\left(\mathrm{NH}_{2}\right)\right), 3120 \mathrm{~m}\left(\mathrm{v}\left(\mathrm{NH}_{2}\right)\right), 2952 \mathrm{vw}$ $\left(\mathrm{v}\left(\mathrm{CH}_{2}\right)\right), 2889 \mathrm{vw}\left(\mathrm{v}\left(\mathrm{CH}_{2}\right)\right), 1614 \mathrm{~m}\left(\delta\left(\mathrm{NH}_{2}\right)\right.$ scissor $)$, $1465 \mathrm{vw}\left(\delta\left(\mathrm{CH}_{2}\right)\right.$ scissor $), 1396 \mathrm{vw}\left(\delta\left(\mathrm{CH}_{2}\right) \mathrm{wag}\right), 1369 \mathrm{vw}$ ( $\delta\left(\mathrm{CH}_{2}\right)$ wag), $1328 \mathrm{vw}\left(\delta\left(\mathrm{NH}_{2}\right)\right.$ wag), $1284 \mathrm{w}\left(\delta\left(\mathrm{CH}_{2}\right)\right.$ twist $)$, 1166w $\left(\delta\left(\mathrm{NH}_{2}\right)\right.$ wag $), 1126 \mathrm{w}, 1103 \mathrm{shvw}\left(\delta\left(\mathrm{NH}_{2}\right)\right.$ twist $)$, 1054s, 1029shvw, 997vw, 916w $\left(v_{\text {sym }}(\mathrm{Mo}=\mathrm{O})\right), 883 \mathrm{~m}$ $\left(v_{\text {asym }}(\mathrm{Mo}=\mathrm{O})\right), 828 \mathrm{vs}(\mathrm{v}(\mathrm{Mo}-\mathrm{O}-\mathrm{Mo})), 716 \mathrm{shw}\left(\delta\left(\mathrm{NH}_{2}\right)\right.$ rock), 640bvs ( $\left.v_{\text {sym }}(\mathrm{Mo}-\mathrm{O}-\mathrm{Mo})\right), 532 \mathrm{~s}, 449 \mathrm{~s}, 405 \mathrm{vw}$, $383 \mathrm{vw}, 358 \mathrm{vs}$.

\subsection{3 $\mathrm{MoO}_{4}\left(1,3-\right.$ dapH$\left._{2}\right) 3$.}

Anal. Calcd for $\mathrm{MoO}_{4}\left(\mathrm{C}_{3} \mathrm{H}_{12} \mathrm{~N}_{2}\right)(236.079 \mathrm{~g} / \mathrm{mol})$ : C, 15.26; N, 11.87; H, 5.12\%. Found: C, 17.90\%; N, 12.23\%; $\mathrm{H}, 5.04 \%$. Selected FT-IR ATR bands $\left(\mathrm{cm}^{-1}\right)$ with assignments based on comparisons to literature data for different compounds: $[14,16,17]$ a broad band between 3000 and $2200 \mathrm{~cm}^{-1}$ may include $\mathrm{v}\left(\mathrm{CH}_{2}\right)$ and vibrations of $-\mathrm{NH}_{3}{ }^{+}$ groups, 2129shvw, $1618 \mathrm{w}, 1521 \mathrm{~m}, 1475 \mathrm{vw}\left(\delta\left(\mathrm{CH}_{2}\right)\right.$ scissor), $1454 \mathrm{vw}\left(\delta\left(\mathrm{CH}_{2}\right)\right.$ scissor $), 1400 \mathrm{vw}\left(\delta\left(\mathrm{CH}_{2}\right)\right.$ wag $)$, $1327 \mathrm{vw}, 1220 \mathrm{vw}\left(\delta\left(\mathrm{CH}_{2}\right)\right.$ twist $), 1195 \mathrm{w}, 1091 \mathrm{vw}, 975 \mathrm{vw}$, 971vw $\left(\nu_{\mathrm{s}}\left(\mathrm{MoO}_{4}\right)\right)$, 900w $\left(\nu\left(\mathrm{MoO}_{4}\right)\right), 808 \mathrm{vs}\left(\nu\left(\mathrm{MoO}_{4}\right)\right)$, 750vs, 503s $\left(\delta_{\mathrm{as}}\left(\mathrm{MoO}_{4}\right)\right), 378 \mathrm{~s}$.

\subsection{4 $\mathrm{WO}_{3}(1,2-$ dap $) 4$.}

Anal. Calcd for $\mathrm{WO}_{3}\left(\mathrm{C}_{3} \mathrm{H}_{10} \mathrm{~N}_{2}\right)(305.974 \mathrm{~g} / \mathrm{mol})$ : C, 11.78 ; N, 9.16; H, 3.29\%. Found: C, 12.13\%; N, 9.25\%; H, 3.21\%. Selected FT-IR ATR bands $\left(\mathrm{cm}^{-1}\right)$ with assignments based on comparisons to literature data for different compounds: $[14,18,19] \nu=3207 \mathrm{bm}\left(v\left(\mathrm{NH}_{2}\right)\right), 3120 \mathrm{~m}\left(v\left(\mathrm{NH}_{2}\right)\right)$, $2946 \mathrm{bvw}\left(\mathrm{v}\left(\mathrm{CH}_{2}\right)\right), 2881 \mathrm{vw}\left(\mathrm{v}\left(\mathrm{CH}_{2}\right)\right), 1614 \mathrm{~m}\left(\delta\left(\mathrm{NH}_{2}\right)\right.$ scissor), $1554 \mathrm{vw}\left(\delta\left(\mathrm{NH}_{2}\right)\right.$ scissor $), 1460 \mathrm{vw}\left(\delta\left(\mathrm{CH}_{2}\right)\right.$ scissor $)$, $1380 \mathrm{vw}, 1378 \mathrm{vw}, 1346 \mathrm{vw}, 1311 \mathrm{vw}, 1228 \mathrm{w}, 1184 \mathrm{w}, 1132 \mathrm{vw}$, 1099m, 1036w, 944w (v(W=O)), 850vs $(v(\mathrm{~W}=\mathrm{O})), 840 \mathrm{sh}$, 818sh, 566bvs (v(W-O-W)), 484w, 458w, 390w, 363vs.

\subsection{Structural Investigations by X-ray Powder Diffraction Methods}

For crystalline structure determination, the X-ray diffraction measurements were carried out on a powder diffractometer Panalytical X'PERT PRO MPD (Cu K $\alpha$ radiation: $40 \mathrm{kV}$ tension, $30 \mathrm{~mA}$ current; PIXcel 1-d detector) working in the Bragg-Brentano geometry. Prior to the measurements the compounds were grounded in the mortar and loaded on a metal holder from the backside to avoid possible texture. For crystal structure determination, the sample was loaded in borosilicate capillary $(2 \mathrm{r}=0.5 \mathrm{~mm})$, and an incident beam was formed by a focusing mirror. The crystalline structures were solved by 'ab initio' direct methods. All the steps of the structure solution, i.e. indexing, space group determination, estimation of the reflection integrated intensities, structure solution and preliminary refinement of the obtained crystal structure models were carried out using EXPO2014 [20]. The final structure models were refined by restrained Rietveld method using JANA2006 [21]. PseudoVoigt was applied as peak shape function, and background was described by Legendre polynomials.

\subsection{Characterization of the Hybrids}

The thermal stability of the compounds in air atmosphere was investigated using a XRK chamber produced by Anton Paar mounted on X'pert Pro diffractometer; the X-ray diffraction data were collected in the temperature range $25-700{ }^{\circ} \mathrm{C}$ and the $2 \theta$ range $5-60^{\circ}$.

Routine X-ray powder diffraction (XRPD) data were collected at ambient temperature on a Philips Analytical Empyrean diffractometer equipped with a PIXcel 1D detector, with automatic data acquisition (X'Pert Data Collector software v. 4.2) using monochromatized $\mathrm{Cu} \mathrm{K} \alpha$ radiation $(\lambda=1.54178 \AA$ ). Intensity data were collected by the stepcounting method (step $0.02^{\circ}$ ), in continuous mode, in the $2 \theta$ 
range $5-60^{\circ}$. Attenuated total reflectance (ATR) FT-IR spectra were measured using a Specac Golden Gate Mk II ATR accessory having a diamond top plate and KRS-5 focusing lenses ( 256 scans, resolution of $4 \mathrm{~cm}^{-1}$ ). Scanning electron microscopy (SEM) images were collected using a Hitachi S4100 microscope operating at $25 \mathrm{kV}$. Samples were prepared by deposition on aluminium sample holders followed by carbon coating using an Emitech K 950 carbon evaporator. The elemental $(\mathrm{C}, \mathrm{N}, \mathrm{O})$ analyses was performed using a Euro Vector EA 300 Elemental Analyzer.

Nitrogen adsorption-desorption isotherms were measured at $-196{ }^{\circ} \mathrm{C}$, using a Quantachrome instrument (automated gas sorption data using Autosorb $\mathrm{IQ}_{2}$ ). The samples were pre-treated at $80^{\circ} \mathrm{C}$ for $2 \mathrm{~h}$, under vacuum $\left(<4 \times 10^{-3} \mathrm{bar}\right)$. The specific surface area was calculated using the Brunauer, Emmett, Teller equation $\left(\mathrm{S}_{\mathrm{BET}}\right)$ and the total pore volume $\left(\mathrm{V}_{\mathrm{p}}\right)$ using the Gurvitch rule (for relative pressure $\left(\mathrm{p} / \mathrm{p}_{0}\right)$ of at least 0.99). The specific external surface area $\left(\mathrm{S}_{\mathrm{ext}}\right)$ and microporous volume $\left(\mathrm{V}_{\text {micro }}\right)$ were calculated using the $\mathrm{t}$-plot method.

\subsection{Catalytic Tests}

Compounds 1-4 were investigated as catalysts for the liquidphase oxidation of unsaturated and saturated hydrocarbons, in batch mode, using cyclic $\mathrm{C} 8$ model substrates, namely ciscyclooctene $(\mathrm{Cy})$ and cyclooctane, facilitating comparisons with literature data reported for different catalysts.

\subsubsection{Cis-Cyclooctene Epoxidation}

In this work, the reaction mixtures consisted of an amount of catalyst equivalent to $18 \mu \mathrm{mol}$ of molybdenum, $1.8 \mathrm{mmol}$ of Cy, $2.75 \mathrm{mmol}$ of oxidant and $1 \mathrm{~mL}$ of organic cosolvent or $300 \mu \mathrm{l}$ of an ionic liquid (IL). The oxidant solutions used were 5-6 $\mathrm{M}$ tert-butyl hydroperoxide in decane (tbhp), or $30 \%$ aqueous $\mathrm{H}_{2} \mathrm{O}_{2}$. 1,2-Dichloroethane (dce), acetonitrile (acn), anhydrous trifluoromethylbenzene (tfmb) or the ILs 1-butyl-3-methylimidazolium tetrafluoroborate $\left([\mathrm{bmim}] \mathrm{BF}_{4}\right)$, butyl-3-methylimidazolium bis(trifluoromethanesulfonyl)imide ([bmim] $\mathrm{NTf}_{2}$ ) or butyl3-methylimidazolium hexafluorophosphate ([bmim] $\mathrm{PF}_{6}$ ) were used as cosolvents. The catalytic tests using $t \mathrm{bhp}$ were carried out in closed borosilicate microreactors of $10 \mathrm{~mL}$ capacity equipped with a Teflon-lined valve for sampling and immersed in a thermostatted oil bath $\left(70{ }^{\circ} \mathrm{C}\right)$, with magnetic stirring (1000 rpm), under air atmosphere. The solution Cy/catalyst/cosolvent was preheated to $70{ }^{\circ} \mathrm{C}$ for $10 \mathrm{~min}$ (under stirring) prior to the addition of the oxidant solution, which was also preheated in a similar fashion. The initial instant of the catalytic reaction was taken as the instant at which the oxidant solution was added to the reactor. Samples were taken periodically. For reactions with $\mathrm{H}_{2} \mathrm{O}_{2}$, individual experiments were performed for a given reaction time, using $\sim 12 \mathrm{~mL}$ borosilicate tubular batch reactors with pear-shaped bottoms, equipped with an appropriate PTFEcoated magnetic stirring bar and a valve. Prior to sampling, the reactors were cooled to ambient temperature.

The samples were analyzed using a Varian3900 gas chromatograph (GC) equipped with a DB-5 capillary column ( $30 \mathrm{~m} \times 0.25 \mathrm{~mm} \times 0.25 \mu \mathrm{m})$ and a FID detector, using $\mathrm{H}_{2}$ as the carrier gas and undecane as internal standard added after the reaction; the experimental range of error was less than $6 \%$, based on replicates carried out for selected experimental conditions. For product identification it was used GC-MS (Trace GC 2000 Series Thermo Quest CE Instruments GC; Thermo Scientific DSQ II) with He as the carrier gas.

The reactions involving an organic cosolvent were biphasic solid-liquid. For the system $4 / \mathrm{Cy} / \mathrm{tbhp} / 70{ }^{\circ} \mathrm{C}$, the solid was separated after $24 \mathrm{~h}$ of reaction by centrifugation (3500 rpm, $10 \mathrm{~min}$ ), thoroughly washed with $n$-hexane, and dried overnight at room temperature and finally under vacuum, at $60^{\circ} \mathrm{C}$ during $1 \mathrm{~h}$. The recovered solid, denoted 4-S, was used in a second batch run, keeping the initial mass ratio of catalyst:Cy:tbhp similar to that for run 1 .

Catalyst recycling was investigated for the reaction system $\mathrm{Cy} / \mathrm{H}_{2} \mathrm{O}_{2} / 3 /[\mathrm{bmim}] \mathrm{BF}_{4}$. After a catalytic batch run, the reactants/products were separated from the IL phase using $\mathrm{n}$-hexane as a extraction solvent (which is immiscible with the IL, and miscible with reactants/products). Specifically, $n$-hexane was added to the reaction mixture, followed by centrifugation, decantation, and removal of the upper liquid phase from the (denser) IL phase. This procedure was repeated five times, allowing the complete removal of reactants/products from the IL phase, as confirmed by GC analysis. Prior to reuse, the IL mixture was heated at $40{ }^{\circ} \mathrm{C}$ under vacuum for $1 \mathrm{~h}$. A second batch run was initiated by adding $\mathrm{Cy}$ and $\mathrm{H}_{2} \mathrm{O}_{2}$ (in equivalent amounts to those used in run 1) to the reactor containing the catalyst/IL mixture.

Iodometric titration was carried out in order to quantify the non-productive decomposition of the oxidant ( $t \mathrm{bhp}$ ) for catalyst 3. The reactors containing the catalyst, solvent and oxidant were heated at $70{ }^{\circ} \mathrm{C}$ for $24 \mathrm{~h}$ (stirring rate of $1000 \mathrm{rpm}$ ). After cooling the reactors to ambient temperature, liquid samples were withdrawn for titration.

\subsubsection{Cyclooctane Oxidation}

Cyclooctane oxidation tests were carried using a Teflonlined stainless-steel batch reactor (1 L capacity), equipped with a magnetic stirrer. The reactor was loaded with catalyst (in an amount equivalent to $3.3 \times 10^{-4} \mathrm{~mol}$ of metal), and substrate $(0.447 \mathrm{~mol}, 60 \mathrm{~mL})$, purged with nitrogen, and then heated to $120^{\circ} \mathrm{C}$. Subsequently, the reactor was pressurized with air to 10 bar. The initial instant of the catalytic reaction was taken as the instant at which the pressure setpoint was 
reached. After $6 \mathrm{~h}$ reaction, the reactor was immersed in a cold-water bath prior to sampling. The reaction products (cyclooctanone and cyclooctanol) were quantified using an Agilent Technologies 6890 N GC equipped with an Innowax column $(30 \mathrm{~m} \times 0.53 \mathrm{~mm} \times 1.0 \mu \mathrm{m})$ and a FID detector, using $\mathrm{N}_{2}$ as carrier gas and chlorobenzene as internal standard. The conversion and yield of products were calculated on the basis of oxygen quantity in the batch reactor.

\section{Results and Discussion}

\subsection{Crystal Structures Description}

The crystal structures of the investigated compounds were solved "ab initio" by direct methods using EXPO2014. Hydrogen atoms were placed in calculated positions during Rietveld refinement procedure (JANA2006). Rietveld refinement plots for compounds 1-4 (Fig. SM-1a-d) and the most relevant interatomic distances (Table SM-1) are given in the Supplementary Material section. The most relevant crystallographic data of structures 1-4 are presented in Table 1.

The structure of $\mathrm{MoO}_{3}$ (1,2-dap) $\mathbf{1}$ is depicted in Fig. 1 . This material is composed of $\mathrm{MoO}_{4} \mathrm{~N}_{2}$ octahedra, which share opposite corners to form separate infinite chains. The (central) Mo atom in each octahedron is connected to two bridging oxo groups $\left(\mathrm{O}-\mu_{2}\right)$, two terminal oxygen atoms and two nitrogen atoms of the $N, N^{\prime}$-bidentate ligand 1,2-diaminopropane (1,2-dap). The molybdenum-oxygen chain is folded, and the bridging Mo-O bond distances are unsymmetrical: $1.86(5)$ and $1.91(5) \AA$, respectively. The organic ligands are arranged alternatively on both sides of the -Mo-O-Mo-O- chain, which is a rarer case; in most cases the organic ligands are attached to the same side of the molybdenum-oxygen chain [2-5]. The Mo-N bonds are relatively long (2.28(4) and 2.33(4) A) which may be due to the strong influence of the terminal oxo groups [4]. The terminal Mo-O bond lengths are 1.82(4) and 1.79(3) $\AA$. Adjacent chains are arranged alternatively with respect to the position of the organic ligands. The synthesis using $\mathrm{WO}_{3}$ instead of $\mathrm{MoO}_{3}$ with the same ligand 1,2-dap led to the isostructural compound $\left[\mathrm{WO}_{3}(1,2-\right.$ dap $\left.)\right] 4$.

The structure of $\mathrm{MoO}_{3}(1,2-$ dae $) 2$ consists of infinite chains of corner-sharing $\mathrm{MoO}_{4} \mathrm{~N}_{2}$ octahedra (Fig. 2), similar to that found for 1. Each $\mathrm{Mo}(\mathrm{VI})$ center is coordinated by one chelating 1,2-diaminoethane (1,2-dae) ligand, two bridging oxo atoms $\left(\mathrm{O}-\mu_{2}\right)$ and two terminal oxo groups. The bridging Mo-O bond distances in the folded chain are 1.92(3) $\AA$, and the terminal Mo-O bond lengths are 1.71(2) and 1.73(1) $\AA$. The 1,2-dae ligands are arranged alternatively on both sides of the -Mo-O-Mo-O- chain. As in the case of $\mathbf{1}$, the relatively long Mo-N bond (2.36(2), 2.16(2) $\AA$ ) may be caused by the strong influence of the terminal oxo ligands [4]. Separate chains are arranged alternatively with a distance of ca. $5.5 \AA$ from each other along the $a$ axis.

Table 1 Crystallographic data for 1-4

\begin{tabular}{|c|c|c|c|c|}
\hline Code and abbreviation & $\begin{array}{l}\mathbf{1} \\
\mathrm{MoO}_{3}(1,2 \text {-dap })\end{array}$ & $\begin{array}{l}\mathbf{2} \\
\mathrm{MoO}_{3}(1,2-\text { dae })\end{array}$ & $\begin{array}{l}\mathbf{3} \\
\mathrm{MoO}_{4}\left(1,3-\text { dapH }_{2}\right)\end{array}$ & $\begin{array}{l}\mathbf{4} \\
\mathrm{WO}_{3} \text { (1,2-dap) }\end{array}$ \\
\hline Chemical formula & $\mathrm{MoO}_{3}\left(\mathrm{C}_{3} \mathrm{H}_{10} \mathrm{~N}_{2}\right)$ & $\mathrm{MoO}_{3}\left(\mathrm{C}_{2} \mathrm{H}_{8} \mathrm{~N}_{2}\right)$ & $\mathrm{MoO}_{4}\left(\mathrm{C}_{3} \mathrm{H}_{12} \mathrm{~N}_{2}\right)$ & $\mathrm{WO}_{3}\left(\mathrm{C}_{3} \mathrm{H}_{10} \mathrm{~N}_{2}\right)$ \\
\hline $\mathrm{M}\left[\mathrm{g} \mathrm{mol}^{-1}\right]$ & 218.0640 & 204.0371 & 236.0793 & 305.974 \\
\hline $\mathrm{a}$ & $6.6507(7)$ & $11.0183(6)$ & $8.3728(2)$ & $6.6256(3)$ \\
\hline $\mathrm{b}$ & $8.7130(4)$ & $7.3981(3)$ & $14.8184(4)$ & $8.80072(13)$ \\
\hline $\mathrm{c}$ & $6.6288(8)$ & $7.4527(5)$ & $6.52623(18)$ & $6.6200(3)$ \\
\hline$\alpha$ & 90.0 & 90.0 & 90.0 & 90.0 \\
\hline$\beta$ & $112.518(3)$ & $94.804(4)$ & $97.8577(16)$ & $113.4342(11)$ \\
\hline$\gamma$ & 90.0 & 90.0 & 90.0 & 90.0 \\
\hline V & $354.83(6)$ & $605.37(6)$ & $802.11(4)$ & $354.17(10)$ \\
\hline $\mathrm{Z} ; \mathrm{d}_{\mathrm{x}}\left[\mathrm{g} \mathrm{cm}^{-3}\right]$ & $2 ; 2.041$ & $4 ; 2.239$ & $4 ; 1.954$ & $2 ; 2.8692$ \\
\hline Space group & $\mathrm{P}$ n; (P 1 n 1) & C $2 ;($ C 121$)$ & $\mathrm{P} 2{ }_{1} / \mathrm{c} ;(\mathrm{P} 12 / \mathrm{c} 1)$ & $\mathrm{P} n ;(\mathrm{P} 1 \mathrm{n} 1)$ \\
\hline 2theta range: start, end, step & $4.013,79.98,0.026$ & $9.011,89.99,0.017$ & $3.00,74.98,0.02$ & $6.013,89.99,0.013$ \\
\hline Number of points, reflections & 2894,428 & 4847,492 & 3600,414 & 6397,574 \\
\hline Number of atoms, parameters, restraints & $19,49,24$ & $16,47,12$ & $22,63,8$ & $19,45,25$ \\
\hline Final $\mathrm{R}_{\mathrm{wp}} / \mathrm{R}_{\mathrm{p}}$ factors & $\begin{array}{l}\mathrm{R}_{\mathrm{p}}=0.0760 \\
\mathrm{R}_{\mathrm{wp}}=0.1021\end{array}$ & $\begin{array}{l}\mathrm{R}_{\mathrm{p}}=0.0861 \\
\mathrm{R}_{\mathrm{wp}}=0.1162\end{array}$ & $\begin{array}{l}\mathrm{R}_{\mathrm{p}}=0.0341 \\
\mathrm{R}_{\mathrm{wp}}=0.0473\end{array}$ & $\begin{array}{l}\mathrm{R}_{\mathrm{p}}=0.0516 \\
\mathrm{R}_{\mathrm{wp}}=0.0676\end{array}$ \\
\hline $\mathrm{R}_{\mathrm{F}}$ and $\mathrm{w} \mathrm{R}_{\mathrm{F}}$ factor & $\begin{array}{l}\mathrm{R}_{\mathrm{F}}=0.0798 \\
\mathrm{wR}_{\mathrm{F}}=0.1177\end{array}$ & $\begin{array}{l}R_{F}=0.0962 \\
w_{F}=0.1158\end{array}$ & $\begin{array}{l}\mathrm{R}_{\mathrm{F}}=0.0210 \\
\mathrm{wR}_{\mathrm{F}}=0.0244\end{array}$ & $\begin{array}{l}\mathrm{R}_{\mathrm{F}}=0.0419 \\
\mathrm{wR}_{\mathrm{F}}=0.0569\end{array}$ \\
\hline Goodness-of-fit & 9.32 & 7.56 & 1.70 & 4.08 \\
\hline CCDC deposition number & CCDC 1908447 & CCDC 1908448 & CCDC 1908449 & CCDC 1908450 \\
\hline
\end{tabular}


Fig. 1 Structure model of hybrid $\mathrm{MoO}_{3}$ (1,2-dap) 1: a $\mathrm{MoO}_{4} \mathrm{~N}_{2}$ octahedra; $\mathbf{b}$ view of the single chain; $\mathbf{c}$ unit cell packing, projection along [101]
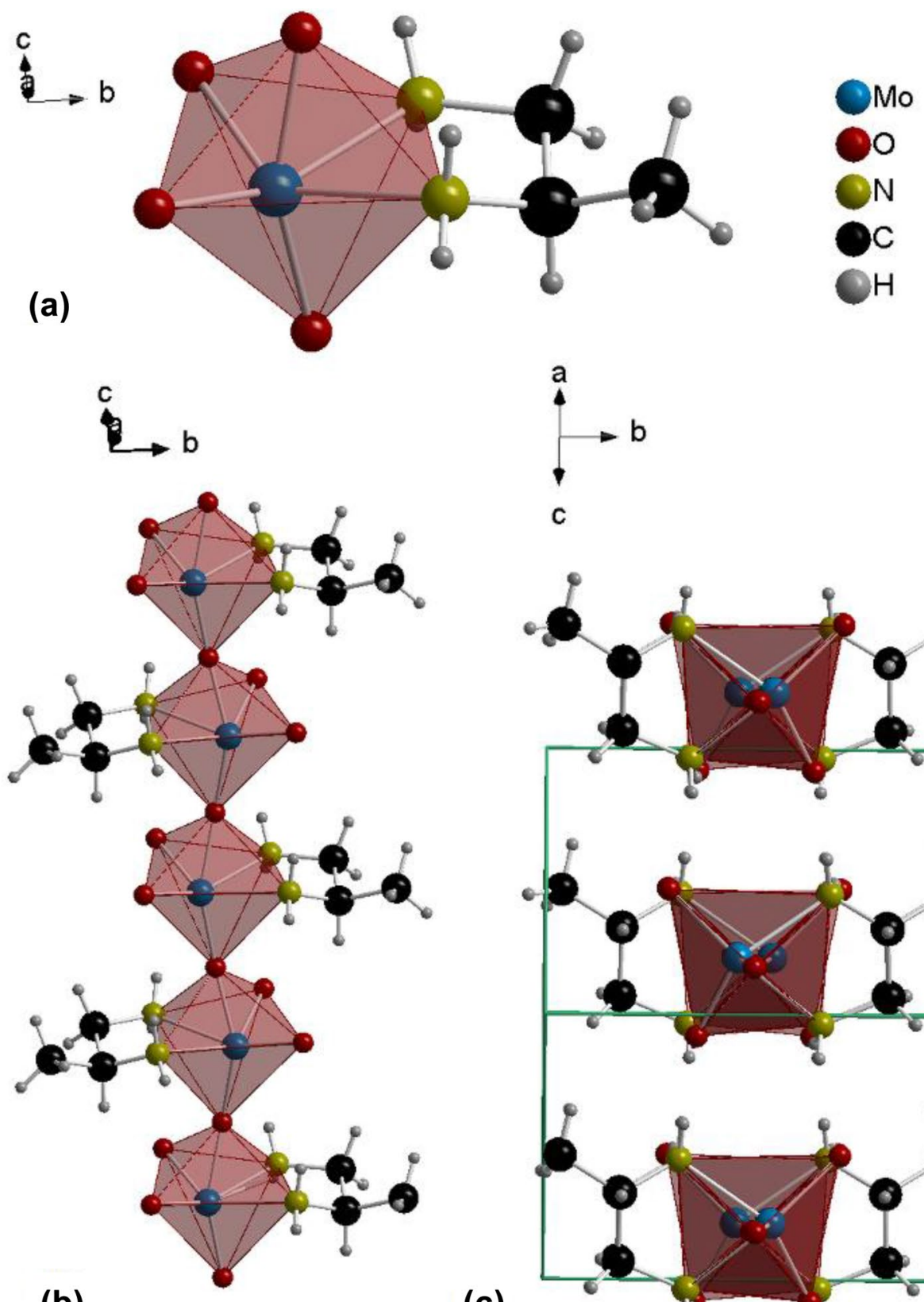

(b)

(c)
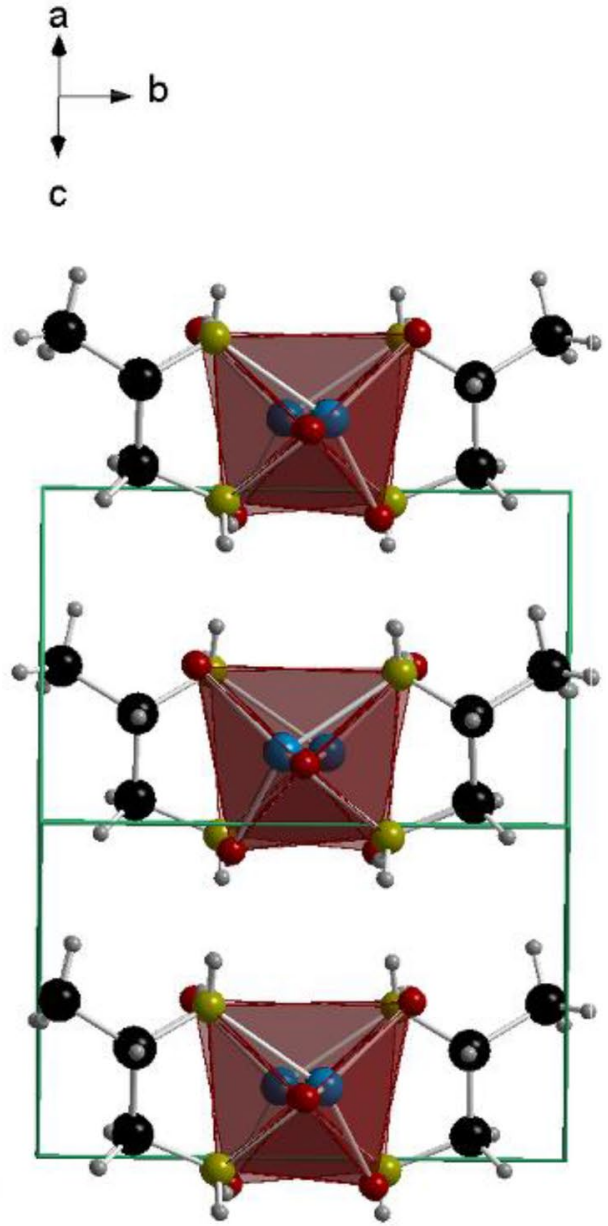

The structural studies indicated that the synthesis using 1,3-diaminopropane as organic ligand led to the compound $\mathrm{MoO}_{4}\left(1,3-\mathrm{dapH}_{2}\right)$ 3, which is a 1,3-diammoniopropane monomolybdate (Fig. 3), in contrast to those verified for the remaining diamine ligands. These results suggest a structure directing effect associated with the type of diamine. Compound 3 consists of anionic $\mathrm{MoO}_{4}{ }^{2-}$ tetrahedra and 1,3-diammoniopropane cations. The Mo-O bond lengths of the $\left\{\mathrm{MoO}_{4}\right\}$ tetrahedra are 1.77(4), 1.70(4), $1.76(3)$ and $1.71(4) \AA$.

\subsection{Complementary Characterization}

The SEM images and elemental (Mo, W) mappings of compounds 1-4 indicated that they consist of micron-sized crystals possessing uniform metal distributions (Fig. 4). Hybrids $\mathbf{1}$ and $\mathbf{4}$ consisted of pseudo-spherical aggregates of thin crystallites (somewhat flake-like for $\mathbf{1}$ and needle-like for 4). Hybrid 2 possessed similar morphological features to $\mathbf{1}$, albeit the crystallites were thicker. The ionic compound $\mathbf{3}$ consisted of somewhat coalesced microcrystals. Nitrogen 
Fig. 2 Structure model of hybrid $\mathrm{MoO}_{3}(1,2$-dae) 2, a $\mathrm{MoO}_{4} \mathrm{~N}_{2}$ octahedra; $\mathbf{b}$ view of the single chain; $\mathbf{c}$ unit cell packing, projection along $b$ axis
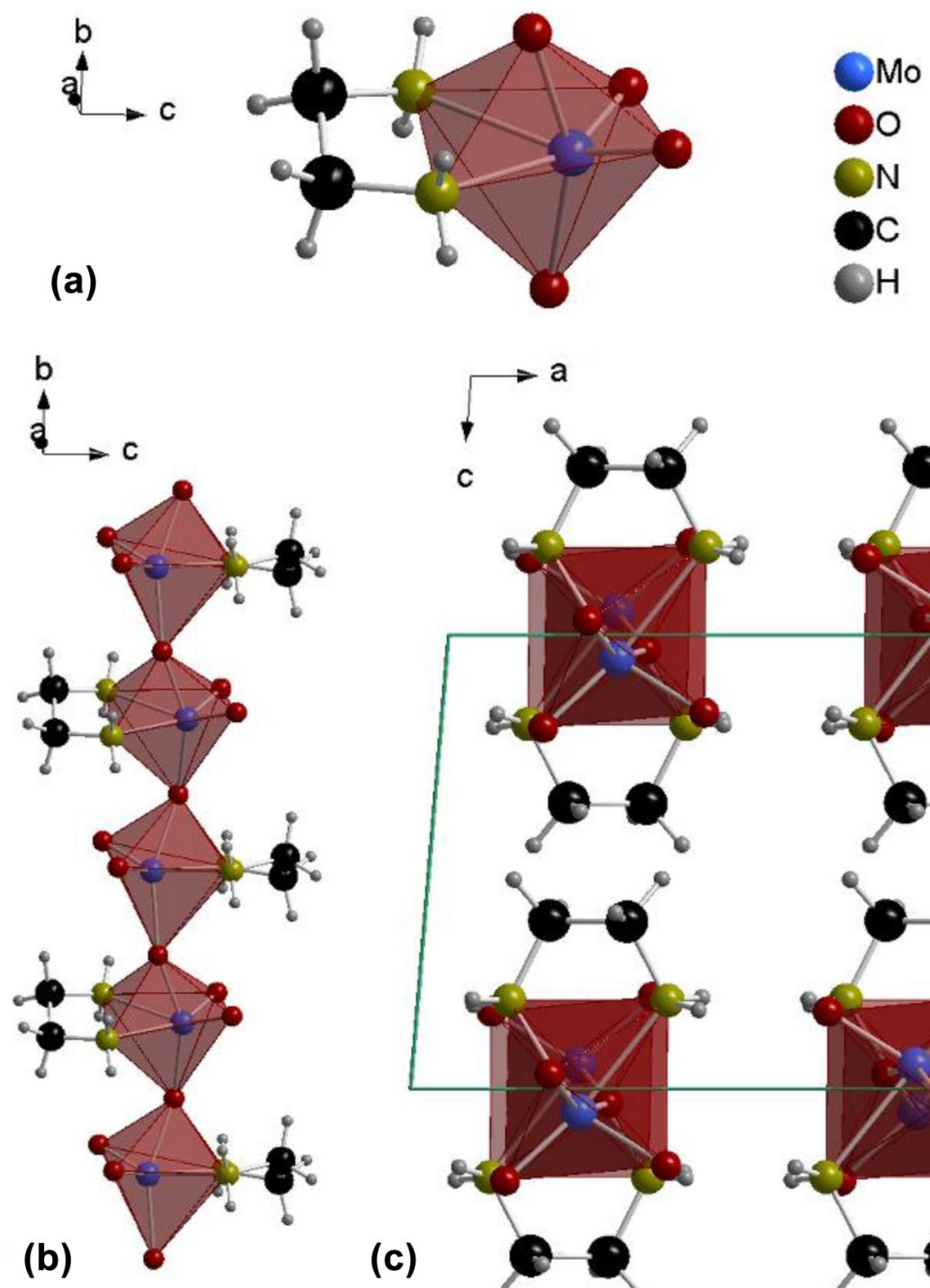

(c)

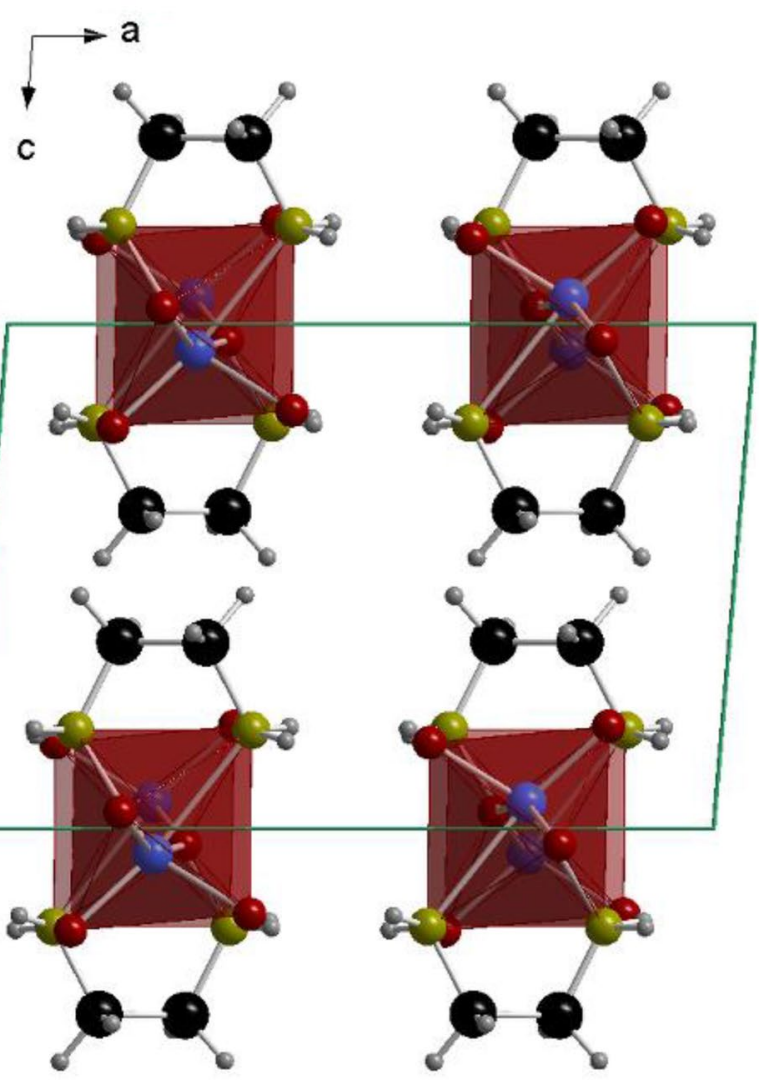

(accordingly, it is difficult to assess the amount of accessible active sites).

Variable-temperature X-ray diffraction studies of $\mathbf{1}$ indicated that it is stable up to ca. $250{ }^{\circ} \mathrm{C}$ (Fig. SM-2). An amorphous phase was formed in the temperature range $250-550{ }^{\circ} \mathrm{C}$; increasing further the temperature led to crystallized $\mathrm{MoO}_{3}$ (ICDD PDF 00-005-0507). Compound 2 was stable up to ca. $225^{\circ} \mathrm{C}$ (Fig. SM-3); an amorphous phase was formed in the temperature range $225-350{ }^{\circ} \mathrm{C}$, and a crystalline phase of $\mathrm{MoO}_{3}$ was formed at $350{ }^{\circ} \mathrm{C}$. These results indicated similar thermal stabilities for $\mathbf{1}$ and $\mathbf{2}$. Compound $\mathbf{3}$ was stable up to $100{ }^{\circ} \mathrm{C}$, above which it became amorphous (Fig. SM-4); at ca. $550{ }^{\circ} \mathrm{C}$, crystalline $\mathrm{MoO}_{3}$ was formed, in parallel to that verified for $\mathbf{1}$ and $\mathbf{2}$. Hence, the hybrids 1, 2 and $\mathbf{4}$ seem to be more stable than the ionic (diammonium monomolybdate) compound 3. Overall, 1-4 are thermally stable at the temperature used for catalytic 
Fig. 3 Structure model of $\mathrm{MoO}_{4}\left(1,3-\mathrm{dapH}_{2}\right) \mathbf{3}$; a asymmetric unit and $\mathbf{b}$ unit cell packing, view along $\mathrm{c}$ axis

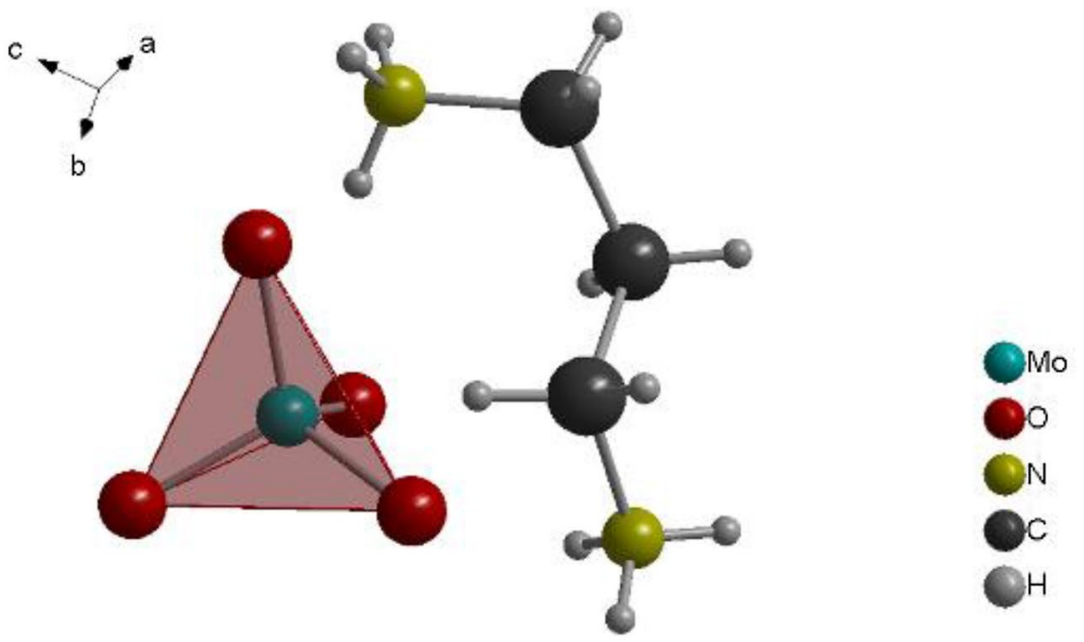

(a)

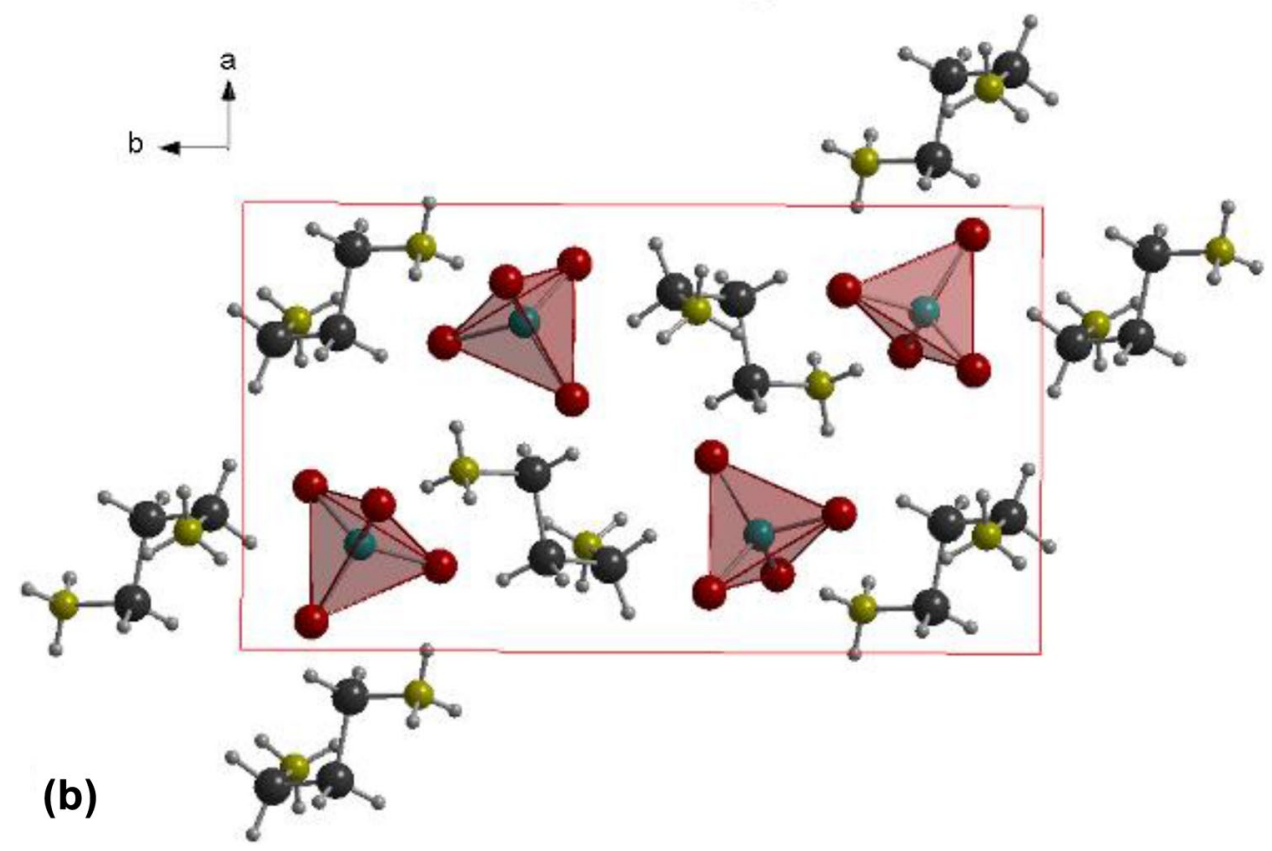

epoxidation and all compounds, excluding $\mathbf{3}$, are stable at the temperature used for catalytic oxidation of cyclooctane (described ahead).

Hybrids $\mathbf{1}$ and $\mathbf{2}$ showed similar FT-IR ATR spectral features in the range $<1000 \mathrm{~cm}^{-1}$, associated with the inorganic scaffold: bands at $630-830 \mathrm{~cm}^{-1}$ are assignable to bridging Mo-O-Mo units [3, 4, 12, 15], and bands at $920-883 \mathrm{~cm}^{-1}$ are assignable to terminal $\mathrm{Mo}=\mathrm{O}$ vibrations (Fig. SM-6.) $[3,4,12,15]$. For 4 , the bands at 944,850 and $566 \mathrm{~cm}^{-1}$ are associated with the presence of terminal $\mathrm{W}=\mathrm{O}$ bonds and bridging $\mathrm{W}-\mathrm{O}-\mathrm{W}$ units $[18,19]$. For isostructural $\mathbf{1}$ and $\mathbf{4}$, the similar spectral features in the range $3210-1000 \mathrm{~cm}^{-1}$ are associated with the ligand 1,2-dap, common to the two hybrids [14]. Compound $\mathbf{3}$ exhibited spectral features in the range $350-520 \mathrm{~cm}^{-1}$ associated with the bending modes and
$700-900 \mathrm{~cm}^{-1}$ due to the stretching modes of $\mathrm{MoO}_{4}{ }^{2-}$ tetrahedra [14, 16, 17]; bands in the range $2000-2200 \mathrm{~cm}^{-1}$ and the broad bands in the range $3000-2200 \mathrm{~cm}^{-1}$ may be partly due to vibrations of $-\mathrm{NH}_{3}{ }^{+}$groups.

Overall, the above results indicate that the organic component (1,2-dae, 1,2-dap, 1,3-dap) may play a structuredirecting role, since polymeric hybrids were obtained using 1,2-dae and 1,2-dap (1, 2 and 4), whereas 1,3-dap led to the ionic mononuclear compound $\mathbf{3}$. The synthesis was repeated using excess of 1,3-dap, and gave the same ionic compound, assessing the synthesis reproducibility. A two-carbon atom distance between the chelating $\mathrm{N}$-atoms of the diamine seems a border line to obtain the one-dimensional hybrids of the type $\left[\mathrm{MO}_{3}(\mathrm{~L})\right]$ possessing simple aliphatic short-chain diamines. Nevertheless, the small distance between the 


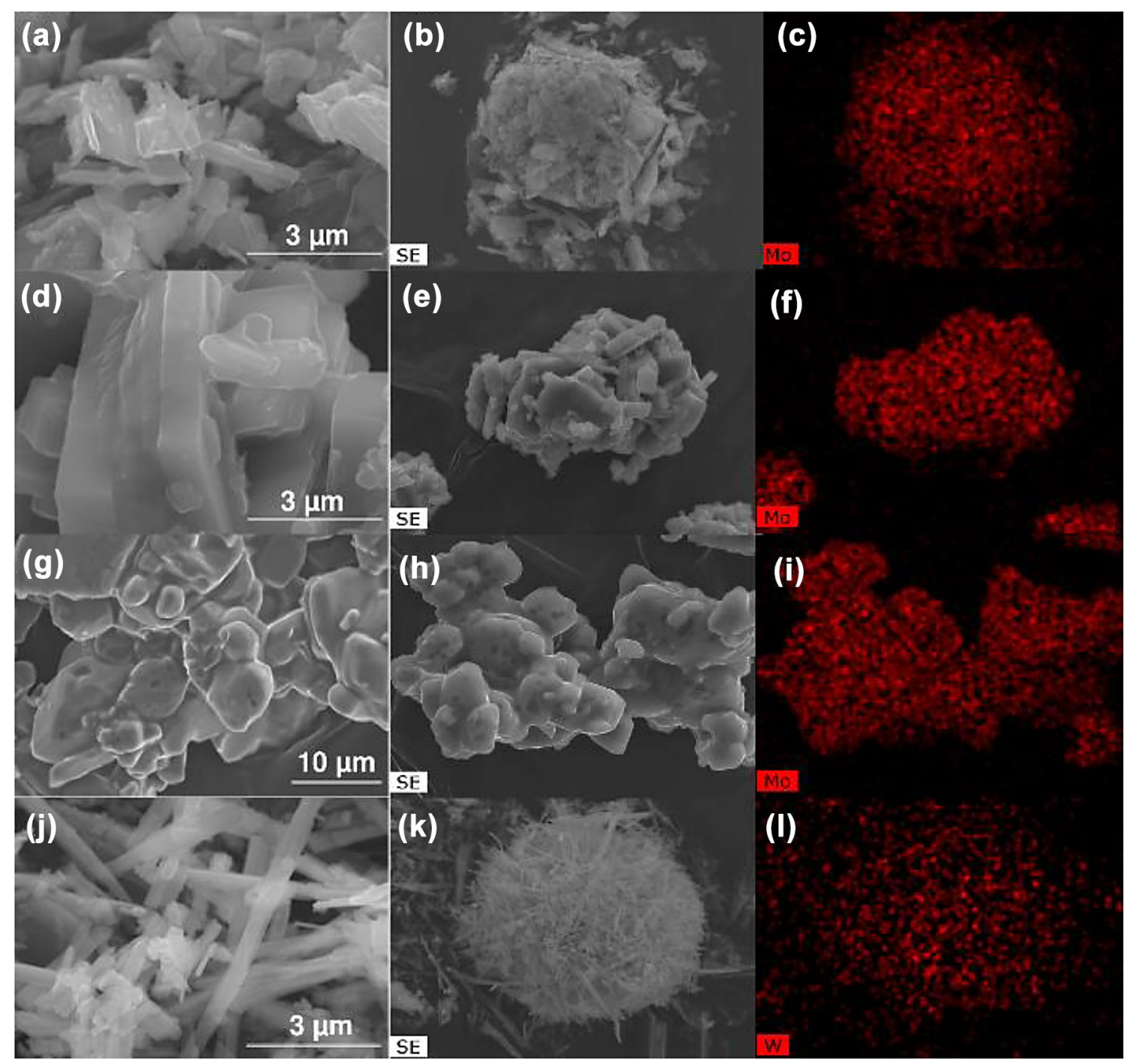

Fig. 4 SEM images and respective metal $(M=M o(c, \mathbf{f}, \mathbf{i})$ or $W(\mathbf{l}))$ distribution mappings of compounds $1(\mathbf{a}, \mathbf{b}, \mathbf{c}), 2(\mathbf{d}, \mathbf{e}, \mathbf{f}), \mathbf{3}(\mathbf{g}, \mathbf{h}, \mathbf{i})$ and 4 $(\mathbf{j}, \mathbf{k}, \mathbf{l})$

amine groups may allow the formation of relatively stable hybrids belonging to the $\left\{\mathrm{MO}_{3}\left(\mathrm{NH}_{2}\right)_{2} \mathrm{R}\right\}$ family.

\subsection{Catalytic Epoxidation}

Compounds 1-4 were tested as catalysts for olefin epoxidation using cis-cyclooctene (Cy) as model substrate, and tert-butyl hydroperoxide ( $t \mathrm{bhp}$ ) as oxidant, in different cosolvents, namely acetonitrile (acn), trifluoromethylbenzene (tfmb) or 1,2-dichloroethane (dce), at $70{ }^{\circ} \mathrm{C}$. Cyclooctene oxide $(\mathrm{CyO})$ was formed in up to quantitative yield at $6 \mathrm{~h}$ reaction (for 1), Table 2, Fig. 5a. The reactions without tbhp and/or catalyst led to negligible conversion, indicating that the oxidant and catalyst are necessary for the reaction to occur, which is consistent with the mechanistic considerations discussed ahead.
In general, the reaction kinetics was favoured using tfmb or dce as cosolvent (up to quantitative epoxide yield at $6 \mathrm{~h}$ ); with acn as cosolvent, conversion at $6 \mathrm{~h}$ was 3-24\% (although up to $80 \%$ conversion was reached at $24 \mathrm{~h}$ for 1 and 2) Fig. 5. These results may be associated with the (non)coordinating properties and polarity of the solvent molecules; tfmb and dce are non-coordinating, whereas acn is coordinating and more polar. Literature data indicated acn as an unfavourable cosolvent for catalysts such as the hybrid $\mathrm{MoO}_{3}(\operatorname{trz})_{0.5}$ (trz $=1,2,4$-triazole) that led to $35 \%$ conversion of Cy with $t \mathrm{bhp}$, at $70{ }^{\circ} \mathrm{C} / 24 \mathrm{~h}$ [22].

A comparative study for the molybdenum catalysts 1-3 in each solvent system, indicated that $\mathbf{1}$ and $\mathbf{2}$ were more active than 3; e.g. 78-94\% conversion for 1 and 2 , compared to $3 \%$ conversion for $3 / \mathrm{Cy} / \mathrm{tbhp} / \mathrm{tfmb}$, at $6 \mathrm{~h}$ (Fig. 5a). The differences in catalytic performances may be related 
Table 2 Cis-cyclooctene (Cy) epoxidation with $t \mathrm{bhp}$, in the presence of catalysts 1,2 and $\mathbf{4}$, and comparison to literature data for for molybdenum and tungsten hybrid compounds possessing $N, N$ '-ligands, tested as catalysts for the same reaction, under comparable conditions

\begin{tabular}{|c|c|c|c|c|c|c|c|c|}
\hline \multirow[t]{2}{*}{ Entry } & \multirow[t]{2}{*}{ Hybrid $^{\mathrm{a}}$} & \multicolumn{4}{|c|}{ Reaction conditions ${ }^{\mathrm{b}}$} & \multirow[t]{2}{*}{ Conv. $^{\mathrm{c}}(\%)$} & \multirow[t]{2}{*}{$\operatorname{Sel}^{\mathrm{d}}(\%)$} & \multirow[t]{2}{*}{ Ref. } \\
\hline & & $\mathrm{T}\left({ }^{\circ} \mathrm{C}\right)$ & Mo:Cy:tbhp & Solv & $\mathrm{t}(\mathrm{h})$ & & & \\
\hline 1 & 4 & 70 & 1:100:153 & dce & $6 / 24$ & $22 / 59$ & $64 / 64$ & - \\
\hline 2 & 4 & 70 & 1:100:153 & tfmb & $6 / 24$ & $11 / 35$ & $84 / 81$ & - \\
\hline 3 & 4 & 70 & 1:100:153 & acn & $6 / 24$ & $14 / 49$ & $100 / 84$ & - \\
\hline 4 & $\mathrm{WO}_{3}\left(2,2^{\prime}\right.$-bipy $) \cdot \mathrm{nH}_{2} \mathrm{O}$ & 70 & 1:100:167 & $\mathrm{tfmb}$ & 24 & 4 & 100 & [18] \\
\hline 5 & $\mathrm{WO}_{3}\left(2,2^{\prime}\right.$-bipy $) \cdot \mathrm{nH}_{2} \mathrm{O}$ & 70 & 1:100:167 & acn & 24 & 8 & 100 & [18] \\
\hline 6 & $\mathrm{WO}_{3}\left(2,2^{\prime}\right.$-bipy $) \cdot \mathrm{nH}_{2} \mathrm{O}$ & 70 & 1:100:167 & dce & 24 & 4 & 100 & [18] \\
\hline 7 & $\mathrm{~W}_{2} \mathrm{O}_{6}(\operatorname{trz})$ & 70 & 1:100:152 & acn & 24 & 9 & 100 & [22] \\
\hline \multicolumn{9}{|c|}{ Mo hybrids } \\
\hline 8 & 1 & 70 & 1:100:153 & dce & $1 / 6$ & $61 / 100$ & $100 / 100$ & - \\
\hline 9 & 1 & 70 & $1: 100: 153$ & $\mathrm{tfmb}$ & $6 / 24$ & $94 / 99$ & $100 / 100$ & - \\
\hline 10 & 1 & 70 & $1: 100: 153$ & acn & $6 / 24$ & $24 / 80$ & $100 / 100$ & - \\
\hline 11 & 2 & 70 & $1: 100: 153$ & dce & $6 / 24$ & $80 / 97$ & $100 / 100$ & - \\
\hline 12 & 2 & 70 & $1: 100: 153$ & $\mathrm{tfmb}$ & $6 / 24$ & $78 / 99$ & $100 / 100$ & - \\
\hline 13 & 2 & 70 & $1: 100: 153$ & acn & $6 / 24$ & $23 / 80$ & $100 / 100$ & - \\
\hline 14 & $\mathrm{MoO}_{3}($ pbim $)$ & 70 & $1: 100: 153$ & $\mathrm{tfmb}$ & $6 / 24$ & $72 / 97$ & $100 / 100$ & [15] \\
\hline 15 & $\mathrm{MoO}_{3}\left(\operatorname{trNH}_{2}\right) \cdot 0.26 \mathrm{H}_{2} \mathrm{O}$ & 70 & $1: 100: 153$ & $\mathrm{tfmb}$ & $6 / 24$ & $45 / 93$ & $100 / 100$ & [25] \\
\hline 16 & $\mathrm{Mo}_{2} \mathrm{O}_{6}(\operatorname{trpzH})\left(\mathrm{H}_{2} \mathrm{O}\right)_{2}$ & 70 & 1:100:153 & $\mathrm{tfmb}$ & $6 / 24$ & $74 / 100$ & $100 / 100$ & [25] \\
\hline 17 & $\mathrm{Mo}_{2} \mathrm{O}_{6}(\mathrm{~m}-\operatorname{trtzH})\left(\mathrm{H}_{2} \mathrm{O}\right)_{2}$ & 70 & $1: 100: 153$ & $\mathrm{tfmb}$ & 6 & 21 & 100 & [25] \\
\hline 18 & $\mathrm{MoO}_{3}(\mathrm{p}$-trtzH $)$ & 70 & $1: 100: 153$ & $\mathrm{tfmb}$ & 6 & 30 & 100 & [25] \\
\hline 19 & $\mathrm{Mo}_{2} \mathrm{O}_{6}\left(\mathrm{p}-\mathrm{tr}_{2} \mathrm{Ph}\right) \cdot \mathrm{H}_{2} \mathrm{O}$ & 70 & $1: 100: 153$ & $\mathrm{tfmb}$ & 6 & 17 & 100 & [25] \\
\hline 20 & $\mathrm{Mo}_{2} \mathrm{O}_{6}\left(\operatorname{tr}_{2} \mathrm{ad}_{2}\right) \cdot \mathrm{H}_{2} \mathrm{O}$ & 70 & $1: 100: 153$ & $\mathrm{tfmb}$ & 6 & 18 & 100 & [25] \\
\hline 21 & $\mathrm{Mo}_{2} \mathrm{O}_{6}(\text { trethbz })_{2} \cdot \mathrm{H}_{2} \mathrm{O}$ & 70 & $1: 100: 153$ & $\mathrm{tfmb}$ & $6 / 24$ & $98 / 100$ & $100 / 100$ & [26] \\
\hline 22 & $\mathrm{MoO}_{3}(\operatorname{trz})_{0.5}$ & 70 & 1:100:153 & acn & 24 & 35 & 100 & {$[22]$} \\
\hline 23 & $\mathrm{Mo}_{3} \mathrm{O}_{9}($ pypz $)$ & 75 & 1:100:153 & $\mathrm{tfmb}$ & $6 / 24$ & $60 / 100$ & $100 / 100$ & [2] \\
\hline 24 & $\mathrm{Mo}_{2} \mathrm{O}_{6}\left(2,2^{\prime}\right.$-bipy $)$ & 55 & $1: 100: 153$ & $\mathrm{tfmb}$ & $6 / 24$ & $\sim 70 / 96$ & $100 / 100$ & [39] \\
\hline 25 & $\mathrm{Mo}_{2} \mathrm{O}_{6}($ pent-pp $)$ & 55 & $1: 113: 172$ & $\mathrm{tfmb}$ & $6 / 24$ & $\sim 95 / 100$ & $100 / 100$ & [27] \\
\hline 26 & $\mathrm{Mo}_{2} \mathrm{O}_{6}$ (pent-pp) & 55 & $1: 113: 172$ & dce & $6 / 24$ & $\sim 78 / 100$ & $100 / 100$ & [27] \\
\hline
\end{tabular}

a2,2'-bipy 2,2'-bipyridine, trz 1,2,4-triazole, pbim 2-(2-pyridyl)-benzimidazole, $\operatorname{trNH}_{2}$ 4-amino-1,2,4triazole, $\operatorname{trpz} H$ 4-(3,5-dimethyl-1H- pyrazol-4-yl)-1,2,4-triazole, $m$-trtzH 5-[3-(1,2,4-triazol-4-ylphenyl)]$1 H$-tetrazole, $p$-trtzH 5-[4-(1,2,4-triazol-4-ylphenyl)]-1H-tetrazole, $p$ - $\operatorname{tr}_{2} P h$ 1,4-phenylene-4,4'-bis(1,2,4triazole, $\quad \operatorname{tr}_{2} a d$ bis(1,2,4-triazol-4-yl)adamantane, trethbz (S)-4-(1-phenylpropyl)-1,2,4-triazole, pypz 2-[3(5)-pyrazolyl]pyridine, pent-pp 2-(1-pentyl-3-pyrazolyl)pyridine

${ }^{\mathrm{b}} T$ reaction temperature, initial molar ratio of Mo:Cy:tbhp, tfmb trifluoromethylbenzene, dce 1,2-dichloroethane, acn acetonitrile

${ }^{\mathrm{c}}$ Conversion of cis-cyclooctene $(\mathrm{Cy})$

${ }^{\mathrm{d}}$ Selectivity to cyclooctene oxide $(\mathrm{CyO})$

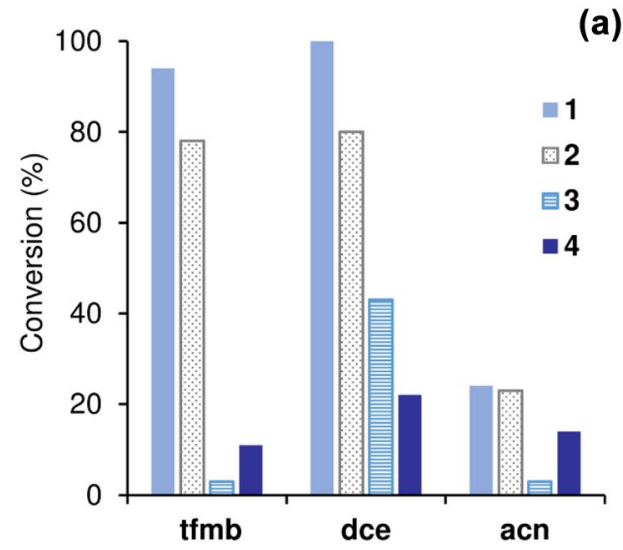

(a)

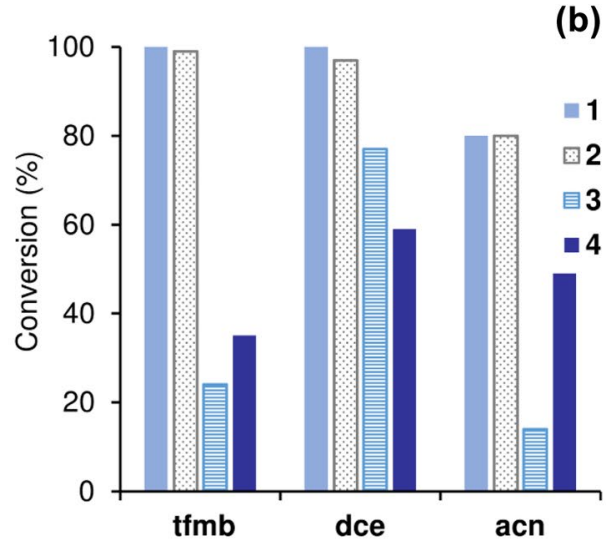


to morphological and/or structure differences. The crystallites were morphologically different. Thus, the catalysts may possess different types and amount of surface defects (e.g. surface terminations lacking the organic component) with distinct intrinsic activities. On the other hand, literature data for anilinium polymolybdate hybrid catalysts indicated that the structure dimensionality had more pronounced effects on the catalytic performances than the distance between chains/layers [23]. Hybrids $\mathbf{1}$ and $\mathbf{2}$ possess 1D structures and similar distance between chains (ca. $5.5 \AA$ ), correlating with their comparably high catalytic activities (based on $78-94 \%$ conversion at $6 \mathrm{~h}$ ). Nevertheless, 1 was somewhat more active than $\mathbf{2}$, which may be due interplay of different factors such as: crystal density (1 possesses a less dense structure than $\mathbf{2}$, Table 1), surface polarity (the distance between chains may alter in the solvent media) and differences in the lengths of terminal $\mathrm{Mo}=\mathrm{O}$ bonds (longer for 1). According to mechanistic studies reported in the literature, the epoxidation of olefins with alkyl hydroperoxides, in the presence of molybdenum or tungsten catalysts, may involve a heterolytic mechanism where the oxidant coordinates to the metal centre with the concomitant protonation of a terminal $\mathrm{M}=\mathrm{O}$ bond (forming $\mathrm{M}-\mathrm{OH}$ ), to give an active oxidizing species; the latter species is involved in a $O$-atom transfer step for olefin epoxidation [24, 25]. Possibly, the longer $\mathrm{Mo}=\mathrm{O}$ bond of $\mathbf{1}$ (Table SM-1) may be more susceptible to protonation in the oxidant activation step, enhancing the reaction kinetics compared to $\mathbf{2}$.

Compounds 1 and $\mathbf{3}$, prepared using diamine isomers (1,2-dap, 1,3-dap) possessed different structural and chemical features, and thermal stability, which may account for their different catalytic performances. Compound $\mathbf{1}$ is a 1D polymeric (neutral) hybrid which was more thermally stable and active than the non-polymeric (ionic) compound $\mathbf{3}$ (Table 2, Fig. 5). Besides the crystalline structure differences, $\mathbf{1}$ and $\mathbf{3}$ possess different coordination spheres which may influence the Lewis acidity necessary for activating the oxidant molecules (based on the above mechanistic considerations). For 1, the diamine acted as a bidentate ligand coordinated to the metal center which is in octahedral coordination. Conversely, for $\mathbf{3}$ the diamine is protonated acting as counterion of the molybdate anion, and molybdenum is in tetrahedral coordination, which may impact on catalytic activity.

A comparative study for the isostructural hybrids $\mathbf{1}$ and 4, possessing the same ligand 1,2-dap and different metal (M), indicated that the catalytic activity and epoxide selectivity were higher for $\mathrm{M}=\mathrm{Mo}$ than the tungsten analogue 4; e.g. quantitative $\mathrm{CyO}$ yield was reached for $\mathbf{1}$, compared to $81 \% \mathrm{CyO}$ selectivity at $35 \%$ conversion for $\mathbf{4}$, at $24 \mathrm{~h}$ ( $t \mathrm{bhp} /$ $\mathrm{tfmb}$ ) (Table 2, Fig. 5). Iodometric titration was carried out for the system $4 / t \mathrm{bhp} / \mathrm{tfmb}$, which indicated negligible nonproductive consumption of the oxidant and thus (undesired) competitive catalase-like activity may be discarded for this catalyst. These results, together with the fact that $t \mathrm{bhp}$ was used in excess, indicated that the poor epoxidation activity of $\mathbf{4}$ is related to its structural features. The solids recovered after the catalytic reaction using $\mathbf{1}$ or $\mathbf{4}$ were characterized by powder XRD (Figure SM-7), SEM and elemental mappings (Fig. SM-8), and FT-IR spectroscopy (Fig. SM-7), which indicated that the crystalline, morphological and chemical features were essentially preserved. No clear correlations could be established between the activities of $\mathbf{1}$ and $\mathbf{4}$ and their (solid-state) textural properties; $\mathbf{1}$ possessed slightly lower specific surface area than the less active catalyst $\mathbf{4}$. However, as mentioned above, one cannot exclude the possibility of the textural properties changing under the catalytic reaction conditions, influencing the reaction kinetics. On the other hand, the two compounds (which possessed essentially external surface area) consisted of pseudo-spherical aggregates of thin crystallites, albeit the crystallites were morphologically different; flake-like and needle-like for $\mathbf{1}$ and 4, respectively. Thus, the catalysts may possess different distributions of surface defects. Moreover, as discussed ahead, the type of transition metal may influence the electronic/ structural features of the active oxidizing species.

The results for $\mathbf{1} / \mathrm{tbhp} /(\mathrm{tfmb}$ or dce) were comparable to those reported for the most active hybrids tested under very similar $\mathrm{Cy} / \mathrm{tbhp}$ reaction conditions (Table 2, entries 21 and 25) [26, 27]. With acn as cosolvent, the activity of 1 surpassed that of $\mathrm{MoO}_{3}(\mathrm{trz})$ (Table 2, entry 22) [22] Tungsten(VI) oxide hybrid polymers were hardly investigated as catalysts for the $\mathrm{Cy} / \mathrm{tbhp}$ reaction, and the results for $\mathbf{4}$ compared favourably to the literature data (under comparable reaction conditions, Table 2, entries 1-7) [18, 22].

Compounds 1-4 were further investigated using $\mathrm{H}_{2} \mathrm{O}_{2}$ as eco-friendly oxidant (water is formed as coproduct) instead

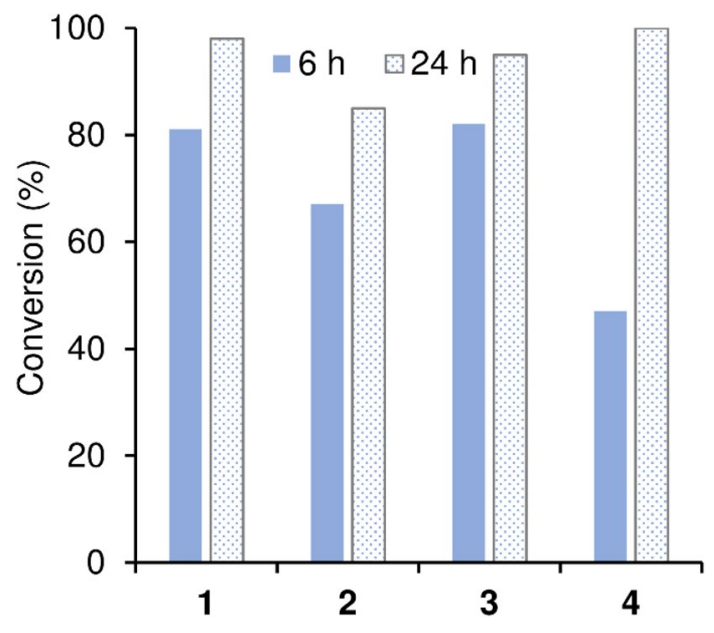

Fig. 6 Conversion of cis-cyclooctene with $\mathrm{H}_{2} \mathrm{O}_{2}$, in the presence of compounds $1-4$, at 6 or $24 \mathrm{~h}, 70{ }^{\circ} \mathrm{C}$ (acn as cosolvent) 
of $t \mathrm{bhp}$; acn was used as cosolvent to enable total miscibility of the olefin and oxidant, and favour kinetic regime (Fig. 6). All compounds prepared performed superiorly using $\mathrm{H}_{2} \mathrm{O}_{2}$ instead of $t$ bhp, especially $\mathbf{3}$. Compound $\mathbf{3}$ resembled closely the performance of $1 ; 100 \% \mathrm{CyO}$ selectivity at $81-82 \%$ conversion, $6 \mathrm{~h} / 70{ }^{\circ} \mathrm{C}$ (Fig. 6). The results for 1 and $\mathbf{3}$ were comparable to the most active Mo hybrids (with $\mathrm{H}_{2} \mathrm{O}_{2}$ ) reported in the literature (Table 3, entries 6, 8-10) [22, 40], and superior to the $1 \mathrm{D}$ hybrid $\mathrm{MoO}_{3}$ (2,2'-bipy) (2,2'bipy $=2,2^{\prime}$-bipyridine) which led to $25 \% / 71 \% \mathrm{CyO}$ yield at $6 \mathrm{~h} / 24 \mathrm{~h}, 70{ }^{\circ} \mathrm{C}$ (ethanol as cosolvent) [18]. Under identical reaction conditions, $\mathrm{MoO}_{3}$ (metal precursor) performed inferiorly (67\% of $\mathrm{CyO}$ yield after $24 \mathrm{~h}$ ) to the molybdenum compounds 1-3 [22]. The tungsten hybrid $\mathbf{4}$ was less active than the molybdenum catalysts, and led to $47 \% \mathrm{CyO}$ yield at $6 \mathrm{~h}$. Nevertheless, the results for $\mathbf{4}$ (quantitative epoxide yield) are comparable to literature data for the 1D hybrid $\mathrm{WO}_{3}$ (2,2'-bipy) $\cdot \mathrm{nH}_{2} \mathrm{O}$ (98\% CyO yield) [18] and superior to the $2 \mathrm{D}$ hybrid $\mathrm{W}_{2} \mathrm{O}_{6}$ (trz) (85\% yield) (Table 3, entries 1-3) [22].
Comparative studies for the isostructural $\mathrm{W}$ and $\mathrm{Mo}$ analogues $\mathbf{1}$ and $\mathbf{4}$, respectively, indicated superior performances for the molybdenum catalyst using $\mathrm{H}_{2} \mathrm{O}_{2}$ or $t$ bhp. Several literature studies reported higher catalytic activity of molybdenum compounds than the tungsten analogues using tbhp [18, 22, 28-35] or $\mathrm{H}_{2} \mathrm{O}_{2},[22,28,35,36]$ as verified in the present work. Mo versus $\mathrm{W}$ analogues may possess different $\mathrm{M}=\mathrm{O}$ bond strengths (which may be weaker for molybdenum counterparts) [37] On the other hand, the influence of the type of oxidant on the types of active species formed in situ for olefin epoxidation in the presence of molybdenum catalysts was demonstrated in theoretical studies [31, 38].

Given the good catalytic performance of the ionic mononuclear compound $\mathbf{3}$ with $\mathrm{H}_{2} \mathrm{O}_{2}$ as eco-friendly oxidant, and its good solubility in several ionic liquids (ILs: [bmim] $\mathrm{NTf}_{2},[\mathrm{bmim}] \mathrm{PF}_{6}$ and $[\mathrm{bmim}] \mathrm{BF}_{4}$ ), a protocol for catalyst recycling mediated by the IL phase was developed (details in the experimental section). The system $\mathrm{Cy} /$ $\mathrm{H}_{2} \mathrm{O}_{2} / 3 / \mathrm{IL}$ led to $37 \%, 78 \%$ and $97 \% \mathrm{CyO}$ yield at $24 \mathrm{~h}$ using the ILs $[\mathrm{bmim}] \mathrm{NTf}_{2}$, [bmim] $\mathrm{PF}_{6}$ and $\left[\mathrm{bmim} \mathrm{BF}_{4}\right.$,
Table 3 Cis-cyclooctene (Cy) epoxidation with $\mathrm{H}_{2} \mathrm{O}_{2}$, in the presence of catalysts $\mathbf{1}, \mathbf{2}$ and $\mathbf{4}$, and comparison to literature data for molybdenum and tungsten hybrid compounds possessing $N, N^{\prime}$-ligands, tested as catalysts for the same reaction

\begin{tabular}{|c|c|c|c|c|c|c|c|}
\hline \multirow[t]{2}{*}{ Entry } & \multirow[t]{2}{*}{ Hybrid $^{\mathrm{a}}$} & \multicolumn{3}{|c|}{ Reaction conditions $^{\mathrm{b}}$} & \multirow[t]{2}{*}{ Conv. $^{\mathrm{c}}(\%)$} & \multirow[t]{2}{*}{ Sel. $^{\mathrm{d}}(\%)$} & \multirow[t]{2}{*}{ Ref } \\
\hline & & $\mathrm{T}\left({ }^{\circ} \mathrm{C}\right)$ & Mo:Cy: $\mathrm{H}_{2} \mathrm{O}_{2}$ & $t(\mathrm{~h})$ & & & \\
\hline \multicolumn{8}{|c|}{ W hybrids } \\
\hline 1 & 4 & 70 & $1: 100: 153$ & $6 / 24$ & $47 / 100$ & $100 / 100$ & - \\
\hline 2 & $\mathrm{WO}_{3}\left(2,2^{\prime}\right.$-bipy $) \cdot \mathrm{nH}_{2} \mathrm{O}$ & 70 & 1:100:167 & 24 & 98 & 100 & [18] \\
\hline 3 & $\mathrm{~W}_{2} \mathrm{O}_{6}($ trz $)$ & 70 & $1: 100: 152$ & 24 & 85 & 100 & [22] \\
\hline \multicolumn{8}{|c|}{ Mo hybrids } \\
\hline 4 & 1 & 70 & $1: 100: 153$ & $6 / 24$ & $81 / 98$ & $100 / 100$ & - \\
\hline 5 & 2 & 70 & $1: 100: 153$ & $6 / 24$ & $67 / 85$ & $100 / 100$ & - \\
\hline 6 & $\mathrm{MoO}_{3}(\operatorname{trz})_{0.5}$ & 70 & $1: 100: 153$ & $6 / 24$ & $89 / 98$ & $100 / 100$ & [22] \\
\hline 7 & $\mathrm{MoO}_{3}\left(\operatorname{trNH}_{2}\right) \cdot 0.26 \mathrm{H}_{2} \mathrm{O}$ & 70 & $1: 100: 153$ & $4 / 24$ & $65 / 89$ & $100 / 100$ & [25] \\
\hline 8 & $\mathrm{Mo}_{2} \mathrm{O}_{6}(\operatorname{trpzH})\left(\mathrm{H}_{2} \mathrm{O}\right)_{2}$ & 70 & $1: 100: 153$ & $4 / 24$ & $97 / 100$ & $100 / 100$ & [40] \\
\hline 9 & $\mathrm{Mo}_{2} \mathrm{O}_{6}(m$-trtzH $)\left(\mathrm{H}_{2} \mathrm{O}\right)_{2}$ & 70 & 1:100:153 & $4 / 24$ & $70 / 96$ & $100 / 100$ & [40] \\
\hline 10 & $\mathrm{MoO}_{3}(p-\operatorname{trtzH})$ & 70 & $1: 100: 153$ & $4 / 24$ & $43 / 93$ & $100 / 100$ & [40] \\
\hline 11 & $\mathrm{Mo}_{2} \mathrm{O}_{6}\left(p-\operatorname{tr}_{2} \mathrm{Ph}\right) \cdot \mathrm{H}_{2} \mathrm{O}$ & 70 & 1:100:153 & $4 / 24$ & $30 / 83$ & $100 / 100$ & [40] \\
\hline 12 & $\mathrm{Mo}_{2} \mathrm{O}_{6}\left(\operatorname{tr}_{2} \mathrm{ad}\right) \cdot \mathrm{H}_{2} \mathrm{O}$ & 70 & $1: 100: 153$ & $4 / 24$ & $29 / 79$ & $100 / 100$ & [40] \\
\hline 13 & $\mathrm{Mo}_{2} \mathrm{O}_{6}(\text { trethbz })_{2} \cdot \mathrm{H}_{2} \mathrm{O}$ & 55 & $1: 100: 153$ & 24 & 77 & 100 & [26] \\
\hline 14 & $\mathrm{MoO}_{3}(\mathrm{pbim})$ & 70 & $1: 100: 153$ & 24 & 16 & 100 & [15] \\
\hline 15 & {$\left[\mathrm{MoO}_{3}(\right.$ bipy $\left.)\right]\left[\mathrm{MoO}_{3}\left(\mathrm{H}_{2} \mathrm{O}\right)\right]_{\mathrm{n}}$} & 70 & $1: 100: 153$ & 24 & 79 & 100 & [41] \\
\hline 16 & $\mathrm{Mo}_{3} \mathrm{O}_{9}([\text { ptapzpy }] \mathrm{Br})_{2}$ & 70 & 1:113:172 & 24 & 51 & $100 / 100$ & [42] \\
\hline 17 & $\mathrm{MoO}_{3}\left(4,4^{\prime}\right.$-bipy $)$ & 70 & $1: 100: 153$ & $6 / 24$ & $45 / 86$ & 100 & {$[6]$} \\
\hline
\end{tabular}

a 2,2'-bipy 2,2'-bipyridine, $\operatorname{trz}$ 1,2,4-triazole, $\operatorname{trNH}_{2}$ 4-amino-1,2,4-triazole, $\operatorname{trpzH}$ 4-(3,5-dimethyl-1Hpyrazol-4-yl)-1,2,4-triazole, $m$-trtz $H$ 5-[3-(1,2,4-triazol-4-ylphenyl)]-1 $H$-tetrazole, $p$-trtz $H$ 5-[4-(1,2,4-triazol-4-ylphenyl)]- $1 H$-tetrazole, $p$ - $t r_{2} P h$ 1,4-phenylene-4,4'-bis(1,2,4-triazole, $\operatorname{tr}_{2} a d$ bis(1,2,4-triazol-4-yl) adamantane, trethbz (S)-4-(1-phenylpropyl)-1,2,4-triazole, pbim 2-(2-pyridyl)-benzimidazole, ptapzpy 2-(1-propyltrimethylammonium-3-pyrazolyl)pyridine, 4,4'-bipy 4,4'-bipyridine

${ }^{\mathrm{b}} \mathrm{T}$ reaction temperature, initial molar ratios of $\mathrm{Mo}: \mathrm{Cy}: \mathrm{H}_{2} \mathrm{O}_{2}$, reaction time (t)

${ }^{\mathrm{c}}$ Conversion of cis-cyclooctene $(\mathrm{Cy})$

${ }^{\mathrm{d}}$ Selectivity to cyclooctene oxide $(\mathrm{CyO})$ 
Table 4 Cyclooctane oxidation with $\mathrm{O}_{2}$, in the presence of catalysts 1-4

\begin{tabular}{|c|c|c|c|c|c|}
\hline \multicolumn{2}{|c|}{ Mo catalyst } & \multirow{2}{*}{$\begin{array}{l}\begin{array}{l}\text { Yield of } \\
\text { ketone } \\
(\%)^{*}\end{array} \\
23.9\end{array}$} & \multirow{2}{*}{$\begin{array}{l}\begin{array}{l}\text { Yield of } \\
\text { alcohol } \\
(\%)^{*}\end{array} \\
5.5\end{array}$} & \multirow{2}{*}{$\begin{array}{l}\text { Total yield }(\%)^{*} \\
29.4\end{array}$} & \multirow{2}{*}{$\begin{array}{l}\text { Molar ratio } \\
\text { ketone/alco- } \\
\text { hol }\end{array}$} \\
\hline 1 & $\mathrm{MoO}_{3}$ (1,2-dap) & & & & \\
\hline 2 & $\mathrm{MoO}_{3}(1,2$-dae $)$ & 12.8 & 3.9 & 16.7 & 3.3 \\
\hline 3 & $\mathrm{MoO}_{4}\left(1,3-\mathrm{dapH}_{2}\right)$ & 1.8 & 0.9 & 2.7 & 2 \\
\hline 4 & $\mathrm{WO}_{3}(1,2$-dap $)$ & 2.2 & 1.0 & 3.2 & 2.2 \\
\hline \multicolumn{6}{|c|}{ Examples of our previous study ${ }^{a}$} \\
\hline B1 & 1,2-phenylenediamine molybdenum oxide & 34.3 & 16.6 & 50.9 & 2.1 \\
\hline B2 & 3,5-dimethylaniline trimolybdate & 29.6 & 15.5 & 45.1 & 1.9 \\
\hline $\mathrm{C} 2$ & 4-methylaniline pentamolybdate & 34.1 & 10.8 & 44.9 & 3.2 \\
\hline D1 & hexagonal $\mathrm{MoO}_{3}$ & 3.9 & 2.7 & 6.6 & 1.4 \\
\hline $\mathrm{D} 2$ & orthorhombic $\mathrm{MoO}_{3}$ & 3.4 & 2.4 & 5.8 & 1.4 \\
\hline
\end{tabular}

* Isolated yields calculated on the basis of oxygen quantity inside the batch reactor

${ }^{a}$ The catalytic activity may depend on many factors, particularly chemical composition, surface area and crystal structure. In previous studies, we reported the influence of selected factors, namely distance between $\left(\mathrm{Mo}_{3} \mathrm{O}_{10}{ }^{2-}\right)_{\infty}$ chains, $\left(\mathrm{Mo}_{5} \mathrm{O}_{16}{ }^{2-}\right)_{\infty}$ layers, surface area, dimensionality of the structures, etc. ${ }^{1,23}$. However, correlations could be formulated for families of similar compounds only. For some geometric factors, like the distance between anionic layers, an 'optimal value' may exist. Generalized structure-activity relationships are not obvious and will continue to be matter of our future research respectively. The best catalytic system $3 /[\mathrm{bmim}] \mathrm{BF}_{4}$ was recovered/reused and led to similar catalytic results for three consecutive batch runs (95-100\% CyO yield after $24 \mathrm{~h}$ ), suggesting good recyclability of $\mathbf{3} / \mathrm{IL}$ for olefin epoxidation with $\mathrm{H}_{2} \mathrm{O}_{2}$.

\subsection{Cyclooctane Oxidation}

Hybrids 1-4 were further investigated as catalysts for the oxidation of cyclooctane (saturated hydrocarbon) with molecular oxygen, at $120{ }^{\circ} \mathrm{C} / 6 \mathrm{~h}$. The products formed were cyclooctanone and cyclooctanol in total yields of up to $29.4 \%$ (Table 4 ). The reaction of cyclooctane $/ \mathrm{O}_{2}$ is more demanding than olefin epoxidation in the presence of the prepared catalysts. Hybrids $\mathbf{1}$ and $\mathbf{2}$ led to superior results to $\mathbf{3}$ and $\mathbf{4} ; 29.4$ and $16.7 \%$ total yield for $\mathbf{1}$ and $\mathbf{2}$, respectively, compared to 2.7 and $3.2 \%$ yield for $\mathbf{3}$ and for $\mathbf{4}$, respectively. Compound $\mathbf{1}$ was more active than $\mathbf{2}$, possibly due to less packed structure (indicated by lower density, Table 1) of the former enhancing active sites accessibility. The poor performance of the ionic compound (3) may be at least partly due to its limited thermal stability (up to $100{ }^{\circ} \mathrm{C}$, compared to at least $200^{\circ} \mathrm{C}$ for the hybrids, Fig. SM-4). The molybdenum hybrid $\mathbf{1}$ performed superiorly to the tungsten analogue $\mathbf{4}$, which is in agreement with literature data for the oxidation of hydrocarbons with $\mathrm{O}_{2}$ [43].

Compounds 1-4 were compared to Mo(VI) compounds investigated by us earlier [1] (Table 4). The poorer-performing catalysts 3 and $\mathbf{4}$ led to similar results to those reported for hexagonal $\mathrm{MoO}_{3}$ (D1 in reference) [1], and commercially available orthorhombic $\mathrm{MoO}_{3}(6-7 \%$ total yield, molar ratio ketone:alcohol =1.4). Compound 1 was slightly less active than the best catalysts investigated by us so far: hybrid 1,2-phenylenediamine molybdenum oxide B1, fibrillar 3,5-dimethylaniline trimolybdate $\mathbf{B 2}$, and layered 4-methylaniline pentamolybdate $\mathbf{C 1}$. The hybrids based on aromatic diamines seem to be more active than those based on aliphatic short-chain diamines. However, in the case of hybrids formed with aliphatic amines, especially $\mathbf{1}$, the yield of ketone is much better (ketone:alcohol $=4.3$ for 1 , compared to 2.1 for B1). Advantageously, $\mathbf{1}$ is thermally stable under the reaction conditions used in the present study and may be reused.

\section{Conclusions}

Hybrid catalysts based on molybdenum or tungsten oxide and aliphatic (simple) short-chain diamines were prepared via eco-friendly protocols using water as solvent under moderate conditions, and starting from commercially available, relatively inexpensive organic and inorganic precursors. The solids consisted of very fine powders, and their crystalline structures were determined by fast and effective powder diffraction techniques. The type of organic component may play a structure-directing role. A two-carbon atom chain between the two amine groups seems a maximum border line to enable the formation of 1D (neutral) hybrids of the type $\left[\mathrm{MoO}_{3}(\mathrm{~L})\right]$, consisting of $-\mathrm{O}-\mathrm{M}-\mathrm{O}-\mathrm{M}$ - chains containing octahedral metal centers where the diamine is a bidentate ligand (one per metal center) spatially arranged in zig-zag along the chains. While the 1,2-diaminopropane (1,2-dap) 
led to the 1D hybrid $\mathbf{1}$, diamine isomer 1,3-diaminopropane (1,3-dap) led to the non-polymeric diammonium monomolybdate $\mathrm{MoO}_{4}\left(1,3-\mathrm{dapH}_{2}\right) \mathbf{3}$, in a reproducible fashion. The best-performing catalyst for cis-cyclooctene (Cy) and cyclooctane oxidation was the hybrid $\mathrm{MoO}_{3}$ (1,2-dap) $\mathbf{1}$. Its tungsten analogue $\mathrm{WO}_{3}$ (1,2-dap) 4 performed inferiorly; e.g. up to $47 \%$ Cy conversion for $\mathbf{4}$, compared to up to quantitative epoxide yield for $\mathbf{1}$, at $70^{\circ} \mathrm{C}$. Overall, the results showed the catalytic potential of simple hybrids based on $\mathrm{MO}_{3}(\mathrm{M}=\mathrm{Mo}, \mathrm{W})$ and aliphatic diamines, obtainable in clean, cheap fashions from commercially available organic and inorganic precursors and using environmentally benign water as solvent.

In the emergence of simple cheap hybrids for diverse applications, it is desirable to investigate the influence of the type of aliphatic diamine and synthesis conditions on properties such as structural density and distances between $\mathrm{MO}_{3}$ centers, aiming at, for example, facilitated access of organic molecules to active sites of the internal surface.

Acknowledgements This work was developed within the scope of the project CICECO-Aveiro Institute of Materials, FCT Ref. UID/ CTM/50011/2019, financed by national funds through the FCT/ MCTES, and the project POCI-01-0145-FEDER-030075 co-funded by POCI (Programa Operacional Competitividade e Internacionalização), FEDER Fundo Europeu de Desenvolvimento Regional) and FCT. P. N. thanks to national funds (OE), through FCT, I.P., in the scope of the framework contract foreseen in the numbers 4,5 and 6 of the article 23, of the Decree-Law 57/2016, of August 29, changed by Law 57/2017, of July 19. The European Union Erasmus + programme [Project Number: 2016-1-PL01-KA103-023786] is acknowledged for providing scholarship (financial support) for the traineeship of B.B. And B.B., M.O., K.P., J.P., W.L. acknowledge partial financial support of the project by the statutory research fund of ICSC PAS and/or FC UJ.

\section{Compliance with Ethical Standards}

Conflict of interest All authors have no conflicts of interest to declare.

Open Access This article is distributed under the terms of the Creative Commons Attribution 4.0 International License (http://creativeco mmons.org/licenses/by/4.0/), which permits unrestricted use, distribution, and reproduction in any medium, provided you give appropriate credit to the original author(s) and the source, provide a link to the Creative Commons license, and indicate if changes were made.

\section{References}

1. Szymanska A, Nitek W, Oszajca M, Lasocha W, Pamin K, Połtowicz J (2016) Catal Lett 146:998-1010

2. Amarante TR, Neves P, Gomes AC, Nolasco MM, Ribeiro-Claro P, Coelho AC, Valente AA, Paz FAA, Smeets S, McCusker LB, Pillinger M, Gonçalves IS (2014) Inorg Chem 53:2652-2665

3. Abrantes M, Amarante TR, Antunes MM, Gago S, Paz FAA, Margiolaki I, Rodrigues AE, Pillinger M, Valente AA, Gonçalves IS (2010) Inorg Chem 49:6865-6873
4. Zapf PJ, Haushalter RC, Zubieta J (1997) Chem Mater 9(9):2019-2024

5. Amarante TR, Neves P, Valente AA, Paz FAA, Fitch AN, Pillinger M, Gonçalves IS (2013) Inorg Chem 52:4618-4628

6. Neves P, Gomes AC, Paz FAA, Valente AA, Gonçalves IS, Pillinger M (2017) Mol Catal 432:104-114

7. Hagrman PJ, Hagrman D, Zubieta J, Maddox J (1999) Angew Chem Int Ed 38:2638-2684

8. Hagrman PJ, LaDuca RL, Koo H-J, Rarig R, Haushalter RC, Whangbo M-H, Zubieta J (2000) Inorg Chem 39:4311-4317

9. Oyama ST (2008) Mechanisms in homogeneous and heterogeneous epoxidation catalysis. Elsevier, Amsterdam, pp 3-99

10. https://ihsmarkit.com/products/chemical-technology-propyleneoxide.html (consulted on the 21st November 2018)

11. Yeoh FH, Lee CS, Kang YB, Wong SF, Cheng SF (2018) J Appl Polym Sci 46861:1-16

12. Amarante TR, Neves $P$, Coelho AC, Gago S, Valente AA, Paz FAA, Pillinger M, Gonçalves IS (2010) Organometallics 29:883-892

13. Yang S, Li G, Tian S, Liao F, Lin J (2007) Cryst Growth Des 7:1246-1250

14. Roe SP, Hill JO, Magee RJ (1991) Monatsh Chem 122:467-478

15. Neves P, Nogueira LS, Gomes AC, Oliveira TSM, Lopes AD, Valente AA, Gonçalves IS, Pillinger M (2017) Eur J Inorg Chem 2017:2617-2627

16. Jendoubi I, Smail RB, Maczka M, Zid MF (2018) Ionics 24:3515-3533

17. Öztürk N, Bahçeli S (2006) Z. Naturforsch. A 61:399-401

18. Amarante TR, Antunes MM, Valente AA, Paz FAA, Pillinger M, Gonçalves IS (2015) Inorg Chem 54:9690-9703

19. Twu J, Fang T-H, Hsu C-F, Yu Y-Y, Wang G-J, Tang C-W, Chen K-H, Lii K-H (1998) J Mater Chem 8:2181-2184

20. Altomare A, Camalli M, Cuocci C, Giacovazzo C, Moliterni A, Rizzi R (2009) J Appl Cryst 42(6):1197-1202

21. Petricek V, Dusek M, Palatinus L (2006) The crystallographic computing system, JANA2006. Czech Republic, Institute of Physics

22. Amarante TR, Neves P, Valente AA, Paz FAA, Pillinger M, Gonçalves IS (2016) J Catal 340:354-367

23. Bożek B, Neves P, Łasocha W, Valente AA (2018) Appl Catal A 564:13-25

24. Veiros LF, Prazeres Â, Costa PJ, Romão CC, Khün FE, Calhorda MJ (2006) Dalton Trans 1383-1390

25. Lysenko AB, Senchyk GA, Domasevitch KV, Hauser J, Fuhrmann D, Kobalz M, Krautscheid H, Neves P, Valente AA, Gonçalves IS (2015) Inorg Chem 54:8327-8338

26. Lysenko AB, Senchyk GA, Domasevitch KV, Kobalz M, Krautscheid H, Cichos J, Karbowiab M, Neves P, Valente AA, Gonçalves IS (2017) Inorg Chem 56:4380-4394

27. Amarante TR, Neves P, Paz FAA, Valente AA, Pillinger P, Gonçalves IS (2014) Dalton Trans 43:6059-6069

28. Schachner JA, Mösch-Zanetti NC, Peuronen A, Lehtonen A (2017) Polyhedron 134:73-78

29. Zhao J, Santos AM, Herdtweck E, Khün FE (2004) J Mol Catal A 222:265-271

30. Khün FE, Xue W-M, Al-Ajlouni A, Santos AM, Zang S, Romão CC, Eickerling G, Herdtweck E (2002) Inorg Chem 41:4468-4477

31. Sözen-Aktaş P, Manoury E, Demirhan F, Poli R (2013) Eur J Inorg Chem 15:2728-2735

32. Herrmann WA, Haider JJ, Fridgen J, Lobmaier GM, Spiegler M (2000) J Organomet Chem 603:69-79

33. Madeira F, Barroso S, Namorado S, Reis PM, Royo B, Martins AM (2012) Inorg Chim Acta 383:152-156

34. Jimtaisong A, Luck RL (2006) Inorg Chem 45:10391-10402 
35. Dupé A, Hossain MK, Schachner JA, Belaj F, Lehtonen A, Nordlander E, Mösch-Zanneti NC (2015) Eur J Inorg Chem 21:3572-3579

36. Kandepi VVKM, Cardoso JMS, Royo B (2010) Catal Lett 136:222-227

37. Wong Y-L, Ma J-F, Law W-F, Yan Y, Wong W-T, Zhang Z-Y, Mak TCW, Ng DKP (1999) Eur J Inorg Chem 1999(2):313-321

38. Comas-Vives A, Lledós A, Poli R (2010) Chem Eur J $16: 2147-2158$

39. Bruno SM, Nogueira LS, Gomes AC, Valente AA, Gonçalves IS, Pillinger M (2018) New J Chem 42:16483-16492

40. Neves P, Lysenko AB, Gomes AC, Pillinger M, Gonçalves IS, Valente AA (2017) Catal Lett 147:1133-1143

41. Gamelas CA, Gomes AC, Bruno SM, Paz FAA, Valente AA, Pillinger M, Romão CC, Gonçalves IS (2012) Dalton Trans 41:3474-3484
42. Nogueira LS, Neves P, Gomes AC, Lavrador P, Cunha-Silva L, Valente AA, Gonçalves IS, Pillinger M (2018) RSC Adv 8:16294-16302

43. Pamin K, Jachimska B, Onik K, Połtowicz J, Grabowski R (2009) Catal Lett 127:167-174

Publisher's Note Springer Nature remains neutral with regard to jurisdictional claims in published maps and institutional affiliations. 